\title{
Mechanisms of Abscisic Acid-Mediated Drought Stress Responses in Plants
}

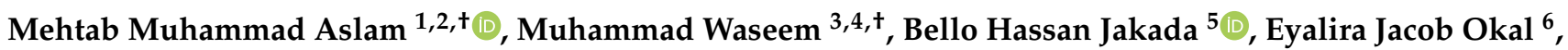 \\ Zuliang Lei ${ }^{1}$, Hafiz Sohaib Ahmad Saqib ${ }^{7}$, Wei Yuan ${ }^{2, *}$, Weifeng Xu ${ }^{1,2}$ and Qian Zhang ${ }^{1, *}$
}

Citation: Muhammad Aslam, M.; Waseem, M.; Jakada, B.H.; Okal, E.J.; Lei, Z.; Saqib, H.S.A.; Yuan, W.; Xu, W.; Zhang, Q. Mechanisms of Abscisic Acid-Mediated Drought Stress Responses in Plants. Int. J. Mol. Sci. 2022, 23, 1084. https://doi.org/ 10.3390/10.3390/ijms23031084

Academic Editor: Ricardo Aroca

Received: 1 December 2021

Accepted: 13 January 2022

Published: 19 January 2022

Publisher's Note: MDPI stays neutral with regard to jurisdictional claims in published maps and institutional affiliations.

Copyright: (C) 2022 by the authors. Licensee MDPI, Basel, Switzerland. This article is an open access article distributed under the terms and conditions of the Creative Commons Attribution (CC BY) license (https:// creativecommons.org/licenses/by/ $4.0 /)$
1 Joint International Research Laboratory of Water and Nutrient in Crop and College of Resources and Environment, Fujian Agriculture and Forestry University, Fuzhou 350002, China; mehtabmuhammadaslam@yahoo.com (M.M.A.); 1200525014@fafu.edu.cn (Z.L.); wfxu@fafu.edu.cn (W.X.)

2 College of Agriculture, Yangzhou University, Yangzhou 225009, China

3 Department of Botany, University of Narowal, Narowal 51600, Pakistan; m.waseem.botanist@gmail.com

4 College of Horticulture, Hainan University, Haikou 570100, China

5 Key Laboratory of Genetics, Breeding and Multiple Utilization of Crops, College of Life Science, Fujian Agriculture and Forestry University, Ministry of Education, Fuzhou 350002, China; bellojakada@gmail.com

6 Center for Mountain Futures, Kunming Institute of Botany, Chinese Academy of Sciences, Kunming 650201, China; eyalirajac@gmail.com

7 Guangdong Provincial Key Laboratory of Marine Biology, College of Science, Shantou University, Shantou 515063, China; sohaibsaqib@gmail.com

* Correspondence: yuanwei@fafu.edu.cn (W.Y.); qian_z@fafu.edu.cn (Q.Z.)

+ These authors contributed equally to this work.

\begin{abstract}
Drought is one of the major constraints to rain-fed agricultural production, especially under climate change conditions. Plants evolved an array of adaptive strategies that perceive stress stimuli and respond to these stress signals through specific mechanisms. Abscisic acid (ABA) is a premier signal for plants to respond to drought and plays a critical role in plant growth and development. ABA triggers a variety of physiological processes such as stomatal closure, root system modulation, organizing soil microbial communities, activation of transcriptional and post-transcriptional gene expression, and metabolic alterations. Thus, understanding the mechanisms of ABA-mediated drought responses in plants is critical for ensuring crop yield and global food security. In this review, we highlighted how plants adjust ABA perception, transcriptional levels of ABA- and drought-related genes, and regulation of metabolic pathways to alter drought stress responses at both cellular and the whole plant level. Understanding the synergetic role of drought and ABA will strengthen our knowledge to develop stress-resilient crops through integrated advanced biotechnology approaches. This review will elaborate on ABA-mediated drought responses at genetic, biochemical, and molecular levels in plants, which is critical for advancement in stress biology research.
\end{abstract}

Keywords: ABA; drought; metabolites; signaling; crop breeding

\section{Introduction}

Drought stress reduces soil water content which restricts water uptake by the plant root thereby limiting plant growth and productivity [1]. Plants have evolved a wide range of morpho-physiological, metabolic, and molecular mechanisms to resist long- or shortterm responses to drought stress [2]. Phytohormones are important plant growth regulators and mediators of environmental stresses such as drought which adversely influence crop yield and pose threats to global food security [2]. To cope with drought stress, potent and novel approaches should be introduced, and phytohormone engineering could be a method of choice for sustainable crop production and breeding programs. In the last decade, the interest to understand the spatiotemporal changes of ABA to modulate plant responses is growing [3]. Abscisic acid (ABA) is critical for plant development and can redesign various physiological and biochemical signal transduction cascades in plants to cope with 
environmental stresses particularly drought [4,5]. Additionally, ABA plays a critical role in biomolecules biosynthesis, senescence, seed germination, stomatal closure, and root architecture modification [6,7].

ABA is classified as an isoprenoid molecule, synthesized from carotenoids (C40) derivative of isopentenyl diphosphate (IPP) through the methylerythritol phosphate (MEP) pathway in plastids [8]. The synthesis of ABA undergoes a series of steps, and each step is catalyzed by a specific enzyme. The conversion of zeaxanthin to all trans-violaxanthin is the first step in ABA biosynthesis occurring in the plastid. This cyclic hydroxylation of epoxycarotenoids to all-xanthin is catalyzed by zeaxanthin epoxidase (ZEP) through an intermediate antheraxanthin. In the next step, cis-isomerization of all trans-violaxanthin to violaxanthin or cisneoxanthin through an unknown enzymatic reaction. After that, 9-cis-epoxycarotenoid dioxygenase (NCED) enzymes split the cis-isomers of violaxanthin and neoxanthin to generate a C15 intermediate product called xanthoxin, finally exported to cytosol. In the cytosol, xanthoxin is converted into ABA through two enzymatic reactions. Next, xanthoxin is first converted to an abscisic aldehyde catalyzed by short-chain alcohol dehydrogenase/reductase (SDR). Finally, the oxidation of abscisic aldehyde to ABA by aldehyde oxidase (AAO) (Figure 1a) [9].

a

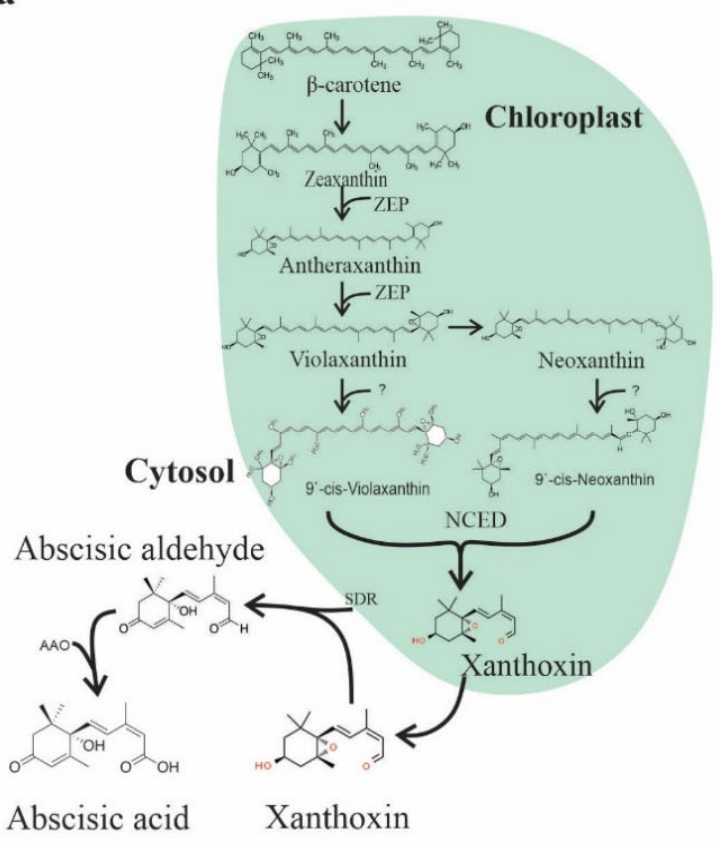

b

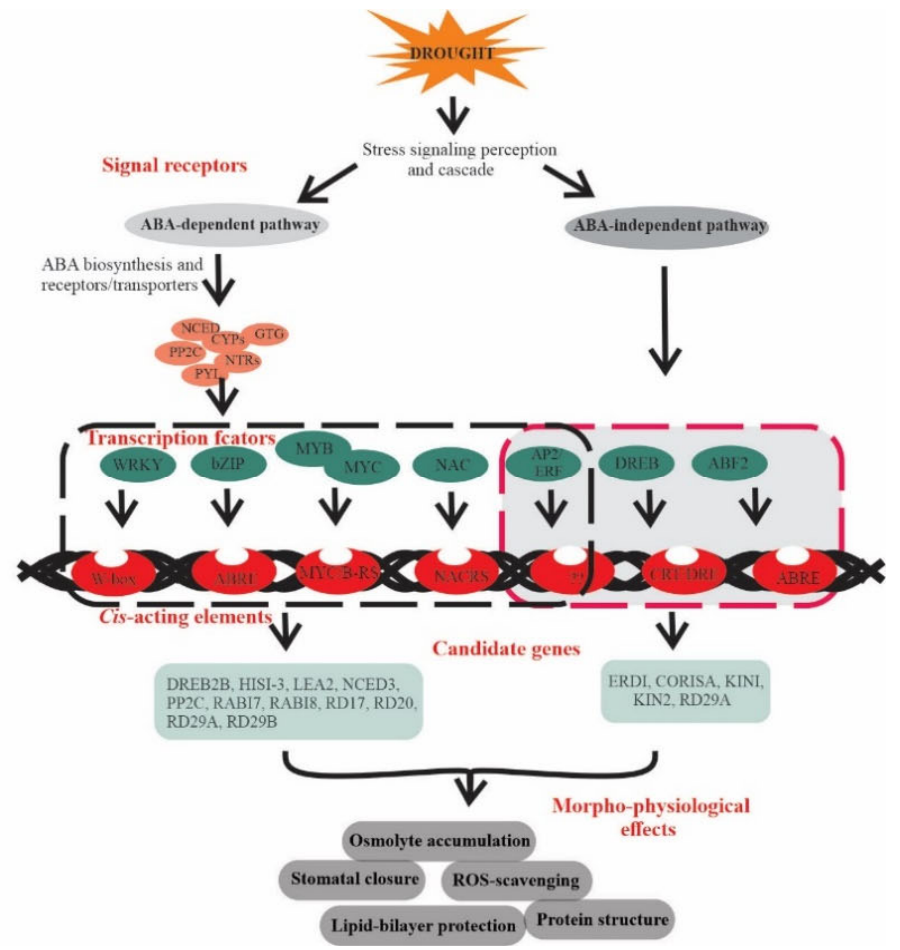

Figure 1. ABA biosynthesis and ABA-mediated drought-responsive pathways in plants. (a) Scheme of ABA biosynthesis. The precursors of $\mathrm{ABA}, \beta$-carotene undergoes a series of oxidative reactions in the plastids and each step is catalyzed by specific enzyme such as ZEP (zeaxanthin epoxidase) or NCED (9-cis-epoxycarotenoid dioxygenase). The derived xanthoxin is exported to the cytosol and converted into ABA through an oxidation reaction mediated by AAO (aldehyde oxidase) and SDR (alcohol dehydrogenase/reductase), (b) ABA-dependent and -independent signaling pathways in the plant, which consists of several core components including ABA receptors and regulators. The ABA-dependent and -independent pathways are indicated by black and red arrows, respectively. Transcription factors (TFs) include bZIPs, MYB/MYC2, NAC (RD26), and WRKY bind to their corresponding cis-acting elements W-box, ABRE, MYB, MYC, DREB2, AREB/ABF, and NACRs.

Plants show a significant increase in ABA levels under drought stress, changes in expression of genes, and induction of ABA biosynthesis enzymes corresponding to mRNA level lead to enhanced ABA accumulation [10]. The transcript abundances of several ABA 
biosynthesis genes, such as ZEP/ABA1, AAO3, 9-cis-epoxycarotenoid dioxygenase (NCED3), and molybdenum cofactor sulfurase (MCSU/LOS5/ABA3), has been upregulated through an ABA-dependent or ABA-independent pathway [11] assisted by binding factors such as $A B F$, MYC MYB, NAC, ERF, bZIP, and DREB/CBF transcription factors (TFs) (Figure 1b) [12].

$\mathrm{ABA}$ is a prime mediator of drought [13] and plays an important role in regulating plant growth, development, and responses to several environmental stresses [14]. Under drought conditions, ABA-mediated stomatal conductance prevents transpiration water loss [10]. Zhang et al. [15] found that multidrug and toxic compound extrusion (MATE) transporter family, detoxification efflux carrier (AtDTX50), participate in ABA transport. ABA receptors such as PYRABACTIN RESISTANCE (PYR), or regulatory component of ABA receptor (RCAR) enhanced ABA responses and confer drought tolerance in Arabidopsis [16]. Similarly, ABA responsive-element binding protein (ABP9) a member of the bZIP family (Figure 1) improves photosynthetic capacity under drought [17]. Histone acetylation has been reported to be critical in ABA-mediated gene regulation to acclimatize plants to drought [18]. It has been shown that mitogen-activated protein kinase (MAPK) signaling cascade plays a critical role in ABA-mediated drought regulation at transcription and proteome level in various plant species including rice, maize, and Arabidopsis $[19,20]$. Altogether, ABA is a pivotal hormone governing plant responses to drought through complex molecular signaling mechanisms. Therefore, exploration of ABA regulators could assist in developing drought-tolerant crops through breeding programs.

The roles of ABA have been extensively studied through the implementation of molecular and genetics approaches, which enable the development of drought-resilient crops. This review is an attempt to underline the role of ABA in drought adaption, avoidance, in different biochemical and physiological responses. Moreover, we also highlighted a concise overview of the molecular mechanism of ABA actions and ABA crosstalk with other hormones in regulating drought stress responses.

\section{ABA: A Key Player under Drought}

Abscisic acid is of prime importance due to its stress-related responses and its involvement in various plant growth processes, making it possible to adapt to drought conditions. Upon drought stress, ABA-mediated stomatal closure reduces water loss by decreasing transpiration rate. Moreover, ABA progressively increases hydraulic conductivity and stimulates root cell elongation, enabling plants recovery from water-limited conditions [21]. Recent advancements in plant genomics accelerated the identification and functional characterization of ABA-dependent candidate genes responsive to drought. For instance, Zhang et al. [15] found that the MATE transporter gene, AtDTX50, is involved in ABA efflux, while mutants of $d t \times 50$ show enhanced tolerance to drought with reduced stomatal conductance relative to WT plants. It is widely acknowledged that ABA binds to pyrabactin-resistance 1 /pyrabactin resistance like/regulatory component of aba receptor (PYR/PYL/RCAR) receptors, the initial step of the core ABA signaling pathway, concerning previously characterized protein phosphatases $2 \mathrm{C}$ (PP2Cs) and sucrose nonfermenting related kinases 2 (SnRK2s) (Figure 1b) [22-24]. The PYR/PYL/RCAR) proteins are reported to be involved in improving drought tolerance in many species such as Arabidopsis, tomato, and rice [25-28].

$\mathrm{ABA}$ has also been reported to regulate calcium-dependent protein kinases (CPK) signaling by inducing $C P K 6$ expression under drought stress. CPKs interact and phosphorylates some core ABA-related TFs, ABFs/AREBs (ABA-responsive element-binding factors) enhancing their transcriptional activities [29]. Similarly, transgenic plants overexpressing ZEP confers tolerance to stresses such as drought [30]. Overexpression of OsbZIP72 showed increased expression of ABA-responsive gene LEAs (late embryogenesis abundant genes) and improved drought resistance in rice, which may be useful for the engineering of droughtresilient crops [31]. Arabidopsis plants overexpressing ABCG25 showed reduced water loss under drought by limiting evapotranspiration. Likewise, mutants of AtABCG40 exhibited more sensitivity to drought [32], indicating the prime importance of ABA-related genes in regulating $\mathrm{ABA}$ responses to drought conditions. 
The ABA hormone has mainly been associated with the regulation of water deficiency in plants. A plethora of studies have shown the critical roles of ABA in regulating genes expression, proteins, and enzymatic activities involved in plant cell dehydration tolerance [33,34]. For instance, the ABA levels were exponentially elevated in Arabidopsis, wheat, rice, tomato, soybean, maize, and sesame under drought [35,36]. Similarly, Wang et al. [37] and Baek et al. [38] demonstrated how multiple genes regulate ABA-mediated drought responses in Arabidopsis, Vigna. radiata, and $V$. angularis. These findings suggest that ABA-mediated drought tolerance is required for plants to fully respond to drought stress.

\section{ABA-Mediated Drought Responses through Physio-Biochemical Alteration}

Plants have evolved distinct adaptive mechanisms to survive and minimize the adverse effect of drought stress [39]. Reactive oxygen species (ROS) serve as a signal molecule that regulates plant responses to stresses. Upon drought, plants synthesize an array of secondary metabolites (SMs) assisting plant survival [40]. ABA is able to synchronize a wide range of functions in plants, facilitating to overcome drought stress [4]. Therefore, to tackle water limitations, dynamic and novel strategies should be formulated and engineered including ROS and SMs as an adaptive strategy to maintain plant growth and productivity.

\subsection{ROS Scavenging System}

Drought and ABA have an intricate relationship [41] that triggers various downstream responses to plant assisting adaption to drought in an ABA-dependent manner [14]. Drought may alter the metabolic and cellular redox status of plants that influence the cellular susceptibility to ABA accumulation [42] suggested the link between metabolic status and ABA signaling [43]. ABA is an indicator of soil water deficit and endogenous ABA concentration rapidly increases to initiate stomatal closure in the plant [44]. Previous studies have also been demonstrated that drought escape induced by water stress depends on ABA. For instance, ABA could improve the plant ability to scavenge ROS by activating antioxidant enzymes [45] such as SOD (superoxide dismutase), POD (peroxidase), CAT (catalase), APX (ascorbate peroxidase), and GR (glutathione reductase) in wheat seedlings under drought, thus regulating the osmotic adjustment, reducing oxidative damage, and improving the conductivity of roots by inducing aquaporin gene expression [45-47]. Kwak et al. [48] showed that $\mathrm{ABA}$ activates $\mathrm{H}_{2} \mathrm{O}_{2}$ biosynthesis in stomata guard cells via a membrane-bound NADPH oxidase causing stomata closure by activating plasma membrane $\mathrm{Ca}^{2+}$ channels [49].

\subsection{Primary Metabolism}

Land plants synthesize diverse primary metabolites (PMs) having higher medicinal and nutritional value which are essential for survival [50]. In general, PMs function in protein-disulfide linkage, redox regulation, methylation reactions, including DNA methylation, mRNA capping, synthesis of phosphatidylcholine, and synthesis of polyamines [51]. Primary metabolites and their associated metabolic genes are considered pivotal factors that contribute to drought tolerance via the involvement of different metabolic pathways [52]. To date, in planta, an estimate of 200,000 metabolites are reported [53]. Among those carbohydrates, nucleosides/nucleotides, and sulfur-containing metabolites were mainly induced by ABA [54]. The major pathways responsible for PMs are glycolysis, the TCA cycle, pentose phosphate pathway, shikimate pathway, aliphatic, and aromatic amino acids which produce secondary metabolites (SMs). Abscisic acid is tightly associated with changes in water availability to fine-tune plant growth [55-60] acting as a signaling molecule for plants to adjust their metabolism and growth in response to drought stress [55].

A. thaliana and Camelina sativa ABA-inducible WSD1 (Wax synthase/acyl-CoA:diacylglycerol acyltransferase) enhanced drought tolerance through leaf and stem wax loading and epicuticular wax accumulation [61]. Canola crop is sensitive to drought, which leads to severe yield losses. However, understanding the genetic basis of ABA-mediated drought tolerance will pave the way to engineering crops with improved drought resistance. Recently, the application of Omics 
approaches identified various ABA-induced and suppressed proteins involved in metabolism, photosynthesis, protein synthesis, membrane transport processes, protein folding/transport and degradation, and stress/defense responsiveness [62]. This finding suggests that various ABA-induced and suppressed metabolites were used as indicators in improving our knowledge of ABA signaling to drought tolerance.

\subsection{Secondary Metabolites}

Plants are surrounded by a complex set of environmental stresses and respond equally to them. Plant metabolites are sensitive to changing environments such as drought [63]. The metabolic profiles of plants have been analyzed to predict their role under drought $[64,65]$. Plants have adapted two distinct strategies including osmotic adjustment [66] and accumulation of specialized secondary metabolites [67] to mitigate drought responses [68]. It has been shown that metabolites such as phenolic compounds, proline, glycine-betaine, soluble sugars, and other compatible solutes accumulated by plants during stress responses. These metabolites maintain water potential, cell turgor maintenance, osmotic adjustment, survival, stabilize proteins and membrane lipid bilayer structures under drought assisting to retain normal physiological processes (Figure 2) [66]. On the other hand, secondary metabolites act as scavengers of free radicals to mitigate oxidative stress in plants under drought stress.

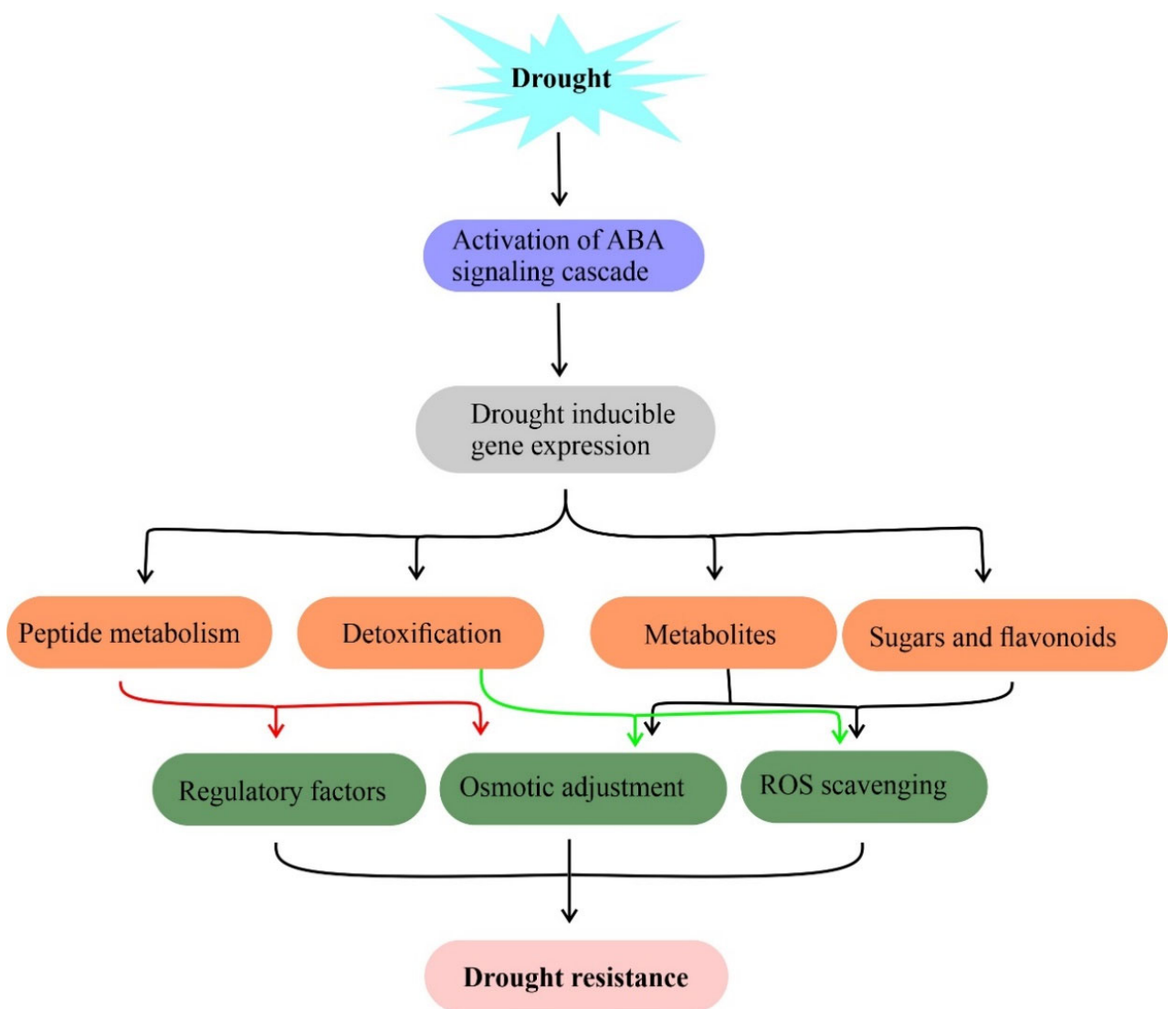

Figure 2. Metabolites and their functions in drought stress tolerance. Drought-induced accumulation of compatible solutes such as sugars, flavonoids, and amino acids for osmotic adjustment, free radical (ROS) scavenging to mitigate drought stress in plants. Genes involved in this metabolite biosynthesis against drought stress are useful in the metabolic engineering of drought resistance.

Metabolic profiling revealed ABA-inducible metabolic networks in response to drought which encourages the accumulation of dehydration-inducible branched-chain amino acids, and key dehydration-inducible genes such as lysine ketoglutarate reductase/saccharopine dehydrogenase (AtLKR/SDH), branch-chain aminotransferase (AtBCAT2), arginine decarboxylase, 
and delta 1-pyrroline-5-carboxylase (P5CS) [69]. For instance, the accumulation of most amino acids such as tryptophan, glutamine, alanine, proline, aspartate, leucine, isoleucine, ornithine, valine, citric acid cycle precursors including cis-aconitate, succinate, and 2oxoglutarate; flavonoids such as cyanidin and quercetin; and lipids such as acylated sterylglycosides and glycosyl inositol phosphoceramides were increased under drought in Arabidopsis [70-72] and a few crop plants, such as maize, barley, and rice [73-75]. In maize, ZmPIS, a phosphatidylinositol synthase, efficiently improved drought tolerance by altering membrane lipid composition and ABA biosynthesis [76]. Overexpression of $A B F 3$ in Glycine max significantly altered various primary and secondary metabolites such as glycerophospholipids, glycolipids, fatty acyls, prenol-lipids, and their derivatives [77].

\section{Alteration in Root System under Drought}

\subsection{Root System Architecture}

The plant root system anchors the plant into the soil and acquires water and minerals from the surrounding for the plant to develop and differentiate [78]. The primitive role of ABA is to modify root architecture, root growth pattern [79], and limit root growth [80], directly correlated with environmental perturbations [78], and in regulating lateral root emergence [81]. Genetic studies on ABA deficient mutants (aba2-1 and aba3-1) exhibit an increased rate of lateral root emergence [82]. This was further evidenced by Gou et al. [83] who found that endogenous ABA biosynthesis requires inhibition of lateral roots in peanuts. Interestingly, ABA-insensitive (abi4) shows an enhanced number of lateral roots [84]. Therefore, instead of ABA levels, ABA signaling is also involved in lateral root formation.

Contrastingly, water stress regulates root cellular integrity and elongation by monitoring respiratory burst oxidase homolog $(\mathrm{RBOH})$ gene expression via ROS secretions [85]. Although, molecular studies on Medicago truncatula mutants specified a significant role of ABA in maintaining root meristem [80]. Studies on ABA-deficient mutants have revealed that $\mathrm{ABA}$ is important to maintain root growth under drought [86]. Recently, Zhang et al. [87] concluded that ABA-mediated root growth of tomatoes under soil drying may involve auxin-dependent processes. ABA deficient mutants vp5 and vp14 develop stunt primary root in maize [88], but primary root elongation is resorted by exogenous IAA in tomato mutant notabilis (not) under drought [87]. However, ABA affects root architecture either positively or negatively based on the genotypic background and environmental conditions, offering a nuanced way to fine-tune the root system to compete with drought stress.

\subsection{Root Secretions}

Root exudates are key drivers that play important role in responses to environmental perturbation [89] and serve as a nutritional or chemoattractant source with $11 \%$ to $40 \%$ of photosynthetically derived carbon $[90,91]$. Root exudates are enriched in organic acids, sugars, fatty acids, amino acids, and secondary metabolites [92], but the type and rate of exudation vary from species to species such as wild oat, grassland species, Brassica napus, and A. thaliana [93-97]. Plant exuded compounds assist in establishing diverse plant-microbial relationships [98] thereby enhancing plant ability to cope with environmental stresses (Figure 3) [99]. ABA acts as a mediator of drought via enhanced osmolytes biosynthesis including proline, organic acids, and protective proteins [100]. Yang et al. [101] demonstrated that ABA concentration was positively correlated with enhanced sucrose phosphate synthase activity and carbon remobilization. As expected, an increased endogenous root ABA concentration may enhance root exudates under water stress [102]. Garriga et al. [103] described that plant metabolites, more specifically ABA was significantly enhanced in root exudation upon drought stress [103]. These findings suggest the possible role of ABA in carbon remobilization and root exudation in mitigating plant stress tolerance (Figure 3). 


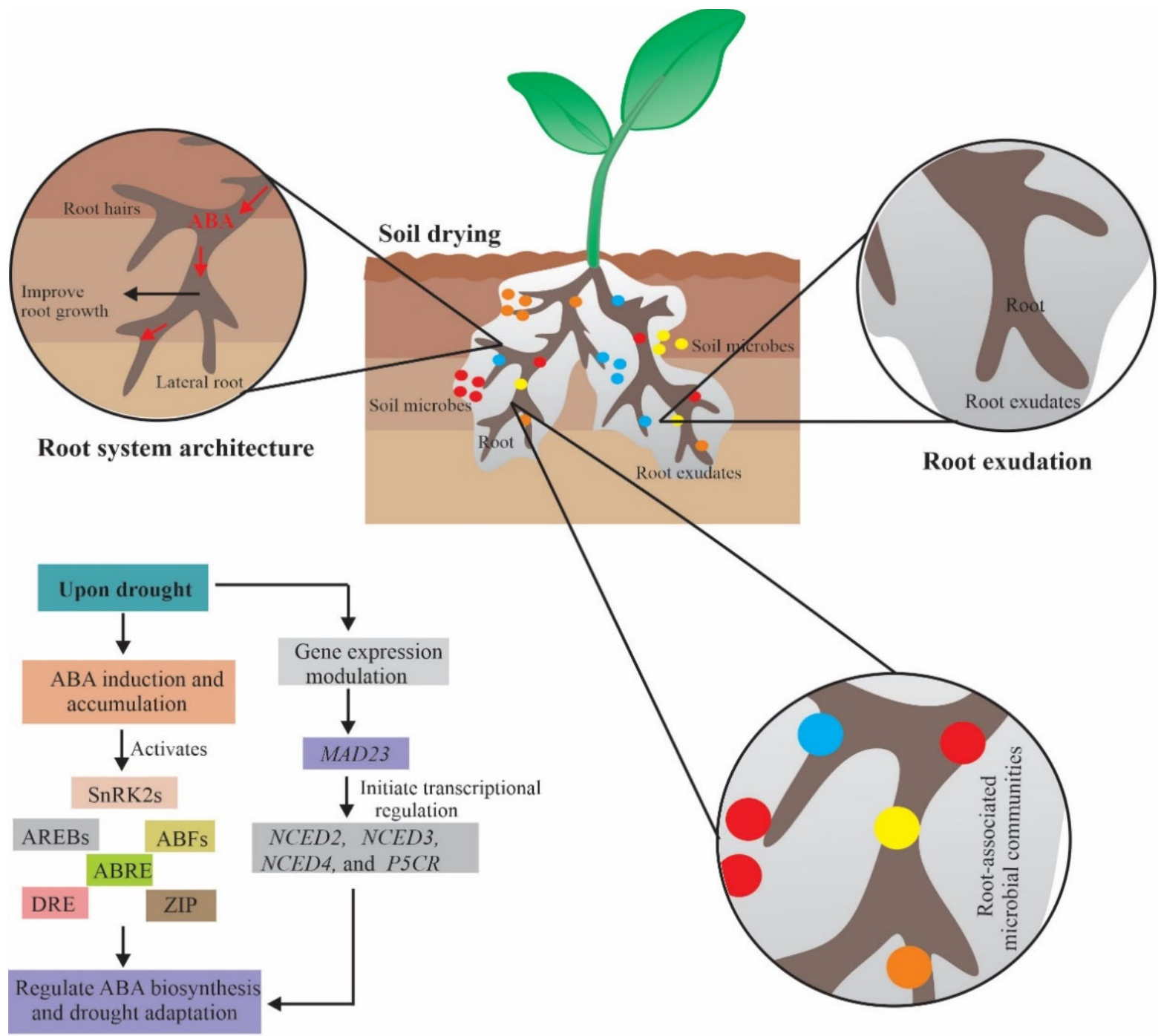

Genetic regulation

Root subterranean environment

Figure 3. Role of ABA in mitigating drought tolerance at root system architecture that includes root exudates, microbial communities at the root-soil interface, and genetic and molecular regulation of various ABA-responsive genes and proteins. Endogenous ABA modulates the root system architecture by promoting root growth, soil microbial communities, and root exudation in response to soil drying. ABA accumulation upon drought led to the activation of TFs and modulates expression of genes responsible for improving ABA-mediated drought tolerance.

Root exudates can adopt specific drought-resistant bacteria. Plant growth-promoting rhizobacteria (PGPR) encouraged the growth of wild-type plants and showed an opposite response in ABA-deficient mutant tomato [104]. Some bacterial species such as Bacillus [105] and B. megaterium [104] establish interaction with plant roots by endogenous ABA [105] promoting plant growth $[106,107]$. Henry et al. [108] reported that in maize organic exudation (including fumaric, malonic, succinic, and oxalic acids) increases under drought, which attracts $B$. subtilis, an important beneficial bacterium that enhances drought resistance of Phleum pretense via osmolytes secretion [109]. These findings suggest that endogenous ABA content is essential for promoting growth.

\subsection{Root Subterranean Environment}

The subterranean environment not only represents the dark region in the soil but also denotes variation in numerous abiotic stress such as temperature, water, and min- 
erals availability. One of the major challenges in ecology is to identify and predict how different species respond to environmental perturbations [110]. Abscisic acid mediates root growth, rhizobacteria abundance, and influences root-hormonal status. For instance, Dodd et al. [111] reported that rhizobacteria can produce, metabolize, and utilize phytohormones / phytohormonal precursors as a nutrient source. The hitherto study showed that rice seed inoculated with P6W and P1Y bacterial strains, ABA concentration was reduced to $14 \%$ by P6W and 22\% by P1Y in the shoot, while root ABA concentration remain intact [112]. In the same study, tomato ABA-deficient mutants flacca $(f l c)$ notabilis (not) inoculated with P6W strains inhibited primary root extension and significantly increased biomass of WT plants [112].

Recently, Gowtham et al. [113] found that CRDT-EB-1 (B. marisflavi) extracted from the rhizosphere of mustard seedlings remarkably increased drought resistance by secreting ABA analog/xanthoxin. Additionally, a study by Porcel et al. [104] described that ABAdeficient mutants flacca and sitiens inoculated with $B$. megaterium showed restricted growth. This study concludes that ABA concentration is essential for B. megaterium growth, which promotes the growth of wild-type plants. Therefore, it may suggest that ABA-metabolizing rhizobacteria can modulate root-phytohormonal status and stimulate plant growth.

\subsection{Biphasic Root Growth Responses}

$\mathrm{ABA}$ is reported to either promote or inhibit root growth and is an inhibitor of plant shoot and root growth under well-watered conditions depending on its concentration. Mild soil drying stimulates root growth but inhibits root growth when it becomes more severe [44]. Similarly, ABA acts as an inhibitor of plant growth under water deficit. The biphasic effects of dry soil on root growth were mild, while water deficit stimulated root growth but severe water deficit inhibited root growth. Furthermore, complex biphasic effects of exogenous ABA on root growth under well-watered conditions were demonstrated by Li et al. [44]; low concentrations of ABA stimulated root growth while high concentrations inhibited root growth.

ABA also inhibits root growth in Arabidopsis by promoting ethylene biosynthesis and auxin influx [114]. In addition, ethylene insensitive mutants etr1-1, ein2-1, and ein3-1, auxin influx (aux1-7, aux1-T), and auxin-insensitive mutants (iaa7/axr2-1) unable to respond to the inhibitory effect of elevated ABA [44]. Furthermore, the stimulatory effect of low ABA concentrations was blocked by auxin efflux inhibitors (pin2/eir1-1) but less pronounced in auxin efflux mutant (iaa7/axr2-1). Taken together, ABA may play a pivotal role in biphasic root growth in plants.

\section{Molecular Mechanism of ABA-Mediated Drought Regulation}

ABA regulates different physiological and molecular responses under drought. Plants perceive stress stimulus in their roots and leaves and transmit the signal to their shoots to synthesize ABA. Protein kinases are positive regulators of ABA signaling, metabolism, and transport in response to drought [115]. For instance, an ABA-responsive G protein receptor (GCR2) caused insensitivity in germination and influenced the expression of ABA inducible genes [116]. Moreover, ABA has been reported to interact with the flowering-time control protein (FCA) and the Mg-chelatase H subunit [117]. Sensors sense drought stimuli on the membrane, and these signals are then passed down through multiple signal transduction pathways, resulting in the expression of drought-responsive genes. Recently, several classes of ABA biosynthesis NCED1, NCED3, ABA2, and AAO3 and transporter proteins AtABCG25 and AtABCG40 localizing in the plasma membrane indicated that plants possess a complex system to sense and respond to fluctuating environmental conditions [118]. Nitrate transporter 1/peptide transporter protein (NPF) named AIT1 initially, mediates ABA uptake into cells, suggesting that this protein could also have a role in intercellular ABA transport [119].

To gain an insight into the genetic regulation of the root system under drought stress, several studies have been investigated. Recently, Zhang et al. [120] reported transcriptomic 
analysis at three time scales $(1 \mathrm{~h}, 3 \mathrm{~h}$, and $7 \mathrm{~h})$ under drought in Pearl millet. It was observed that a total of 2004, 1538, and 605 genes were differentially expressed at $1 \mathrm{~h}, 3 \mathrm{~h}$, and $7 \mathrm{~h}$, respectively, while 12 genes were upregulated at all the time scales. Some of these highly expressed genes were related to the MAPK signaling pathway, metabolic processes, and plant hormonal signaling such as the ABA signal transduction pathway. This may provide a genetic basis to understand drought resistance mechanisms in other plants. Similarly, Li et al. [121] showed that OsMAD23 serves as a positive regulator for altering ABA biosynthesis to enhance drought tolerance in rice. OsMAD23 encourages endogenous ABA accumulation through its biosynthesis and proline accumulation by activating several ABA and proline biosynthesis genes including OsNCED2/3/4 and OsP5CR. These findings suggest a new way to enhance drought/salt resistance in rice.

The expression of several TFs is controlled by ABA such as AREBs, ABFs, DRE, ABRE, and several others (Figure 3). Indeed, transactivation analysis revealed that the ABAresponsive TF factor OsBZIP72 activates the expression of OsSWEET13 and OsSWEET15 by binding with their promoters mediating sucrose transportation and distribution in rice under drought and other stresses [122]. It has also been found that Arabidopsis ZmbZIP33 remarkably improved chlorophyll content and root length as a drought-adapted strategy in maize [123]. A few popular studies demonstrating the role of ABA-mediated drought tolerance are listed in Table 1.

Table 1. Some important genes or transporters for improved drought tolerance through modulating ABA signaling pathway in plants.

\begin{tabular}{|c|c|c|c|}
\hline Plant Species & Gene/Transporter & Function & References \\
\hline \multirow[t]{4}{*}{ Agrostis grass } & VuNCED1 & Increased 3-4-fold plant biomass & [124] \\
\hline & AtABCG17-18 & $\begin{array}{c}\text { Stomatal conductance, and increased water use } \\
\text { efficiency }\end{array}$ & [125] \\
\hline & AtPDR12/ABCG40 & ABA uptake transporter & [32] \\
\hline & AIT1/NRT1.2 & ABA importer important for stomatal aperture & [126] \\
\hline \multirow[t]{5}{*}{ Arabidopsis thaliana } & $A t B B D 1$ & $\begin{array}{l}\text { Increased expression of } \mathrm{ABA} \text { and drought-responsive } \\
\text { genes }\end{array}$ & [127] \\
\hline & AtSAUR32 & Highly induced by abscisic acid and drought treatment & [128] \\
\hline & AtbHLH68 & Lateral root elongation in response to drought & [129] \\
\hline & AtHDA9 and $A B I 4$ & $\begin{array}{c}\text { Regulate CYP707A1 and CYP707A2 expression under } \\
\text { drought }\end{array}$ & [130] \\
\hline & AtDTX/MATE & Facilitate ABA efflux and tolerance to drought & [15] \\
\hline Brachypodium distachyon & $B d A B C G 25$ & Regulate intercellular ABA transport & [131] \\
\hline Brassica napus & BnFTA & Improved under drought conditions & [132] \\
\hline Glycine max & GmCIPK2 & ABA signaling and drought tolerance & [133] \\
\hline \multirow[t]{2}{*}{ Nicotiana tabacum } & SgNCED1 & $\begin{array}{c}\text { Enhanced ABA accumulation increased drought } \\
\text { tolerance }\end{array}$ & [134] \\
\hline & Oshox22 & Increased ABA content, and enhanced drought tolerance & [135] \\
\hline \multirow[t]{2}{*}{ Oryza sativa } & OsbZIP46CA1 & Improved drought resistance & [136] \\
\hline & OsPM1 & ABA influx carrier is important in drought responses & [137] \\
\hline Petunia & LeNCED1 & $\begin{array}{c}\text { Elevated levels of ABA and proline, increases drought } \\
\text { resistance }\end{array}$ & [138] \\
\hline Setaria italica & $\begin{array}{l}\text { SiARDP target of } \\
\text { SiAREB }\end{array}$ & ABA-dependent signal pathways & [139] \\
\hline \multirow{2}{*}{ Solanum lycopersicum } & SlGRAS42s & ABA signaling & [140] \\
\hline & $P Y R / P Y L / R C A R$ & Role in seed germination and basal ABA signaling & [141] \\
\hline Triticum aestivum & HVA1 & Improved growth characteristics under water deficit & [142] \\
\hline Vigna unguiculata & VuABCG25 & Involved in ABA signaling pathway under water stress & [143] \\
\hline Vitis vinifera & VviNCED1, VviNCED2 & ABA synthesis in response to plant water status & [144-146] \\
\hline Xanthoceras sorbifolium & XsWRKY20 & Regulate drought tolerance by ABA signaling pathway & [147] \\
\hline Zea mays & ZmXerico1-2 & $\begin{array}{l}\text { Improved water use efficiency, yield under drought } \\
\text { stress }\end{array}$ & [148] \\
\hline
\end{tabular}




\section{ABA Dependent Translational and Posttranslational Modification}

Post-transcriptional regulation such as alternative splicing and RNA-mediated silencing, and post-translational regulation such as protein activity, subcellular localization, and protein half-life significantly contribute to the fine-tuning of ABA-dependent plant response drought stress.

Post-transcriptional regulation of an ABA-responsive basic leucine zipper (bZIP) TF ABI5 has been studied extensively in response to various stresses, particularly drought. For instance, ABI5 represses/activates the expression of various ABA-dependent receptors and kinases and stimulates plant adaptation to drought stress $[149,150]$. Several members of the bZIP family (ABF1-4) were shown to be highly redundant to ensure ABAmediated adaptation to drought in various species such as in Arabidopsis, rice, cotton, carrot, and barley [151-155]. ABI5 interaction is activated through phosphorylation by kinases SRK2D/SnRK2.2, SRK2E/SnRK2.6/OST1, SRK2I/SnRK2.3, SOS2-like protein kinase 5/CIPK11, glycogen synthase kinase 3-like kinase BRASSINOSTEROID INSENSITIVE 2 (BIN2) and calcineurin B-like interacting protein kinase 26 (CIPK26), which suppress or activate $\mathrm{ABI} 5$ post-translation under ABA treatment. Therefore, $\mathrm{ABI} 5$ protein regulation could serve as a model to study the activity and stability of critical components engaged in drought tolerance affecting posttranslational modification. Various key components in drought and ABA signaling under post-translational modifications result in modulation of drought responses indicating their role in stress adaptation (Table 2).

Table 2. Post-translational modifications and their predicted role in plants responsive to drought and ABA signaling in different plant species.

\begin{tabular}{cccccc}
\hline Plant Species & Protein & Target & Role in Plants & References \\
\hline Arabidopsis & PUB22/23 & RPN12a & Drought tolerance and ABA signaling & {$[156]$} \\
Arabidopsis & PUB19 & nd & Drought tolerance & {$[157]$} \\
Arabidopsis & AIRP1 & nd & ABA-dependent drought tolerance & {$[158]$} \\
Arabidopsis & Rma1 & PIP2;1 & Drought tolerance & {$[159,160]$} \\
Arabidopsis & SDIR1 & SDIRIP1 & Drought and salinity tolerance, ABA signaling & {$[161]$} \\
Arabidopsis & XERICO & nd & Drought stress tolerance, ABA biosynthesis & {$[162]$} \\
Arabidopsis & DOR & nd & nd & Drought tolerance and ABA response & {$[163]$} \\
Rice & RING-1 & nd & {$[164]$} \\
Maize & ZF1 & nd & Drought tolerance and ABA signaling & {$[165]$} \\
\hline
\end{tabular}

\section{Hormone Crosstalk}

In plants, hormones secreted from predominantly vascular cells and guard cells and transported to distant target sites through the plant body circulatory system, suggesting that most plant hormones are mobile. When plants are exposed to environmental stress the ABA signaling cascade is rapidly activated, which in return activates ABA-responsive TFs and induces the expression of ABA-responsive genes [166]. ABA interacts with other hormones including auxin, gibberellins (GA), cytokinin (CK), ethylene (ET), salicylic acid (SA), and jasmonic acid (JA) to help the plant to withstand abiotic stresses such as drought. Phytohormonal engineering is a major environmental stress mediator, particularly ABA, a prime regulator of environmental stress tolerance. $\mathrm{ABA}$ is produced in shoot and roots but enhanced accumulation is stimulated by a decrease in cellular turgor [167]. However, ABA accumulation is directly correlated with plant/tissue water status, but the underlying molecular mechanism of ABA accumulation and drought sensation is still unclear.

Stress response in plants is regulated by integrating ABA and auxin signals [168]. Some studies revealed that $\mathrm{ABA}$ and auxin distribution within the primary roots and lateral roots are independent of each other because they show different localization patterns. Furthermore, auxin biosynthesis was inhibited by ABA, but ABA accumulation modulates auxin transport in the root tip of Arabidopsis during drought $[169,170]$. Some authors argue that auxin and ET are required for ABA response in the root [171]. Furthermore, auxin/ET/ABA crosstalk was examined, and it was found that auxin and ET likely 
operate in a linear pathway to affect ABA-responsive inhibition of root elongation, and probably act independently to affect ABA-responsive inhibition of seed germination [171]. Exogenous application of JA encourages foliar ABA accumulation while JA deficiency suppresses ABA levels [172,173], suggesting extensive crosstalk between JA-ABA pathways. Puértolas et al. [174] demonstrated that ABA concentration increase with declining plant water status while JA accumulates during early stages of stress, however, the molecular and physiological involvement of JA in concert with ABA is still unclear.

Abscisic acid enables plants to cope with several abiotic stresses by interacting with important ABA-related TFs and by coordinating with other plant hormones. For instance, ABA-related DREB (dehydration-responsive element binding), nced (9-cis-epoxycarotenoid dioxygenases), and MYB (myeloblastosis) TFs are known to regulate intracellular pathways involved in CK homeostasis [175]. AtMYB2 knockout led to enhanced expression of IPT1/4/5/6/8 (adenosine phosphate-isopentenyl transferases), suggesting the role of AtMYB2 in CK synthesis [175]. Similarly, overexpression of MsDREB6.2 (dehydrationresponsive gene) resulted in increased $M d C K X 4 a$ expression, thereby reducing endogenous $\mathrm{CK}$ and enhancing drought tolerance of transgenic apple plants [176].

In Arabidopsis, the SnRK2 protein interacts with CK signaling-ARR5 (type-A RR5) and regulates ABA-mediated drought tolerance [177]. In addition, ET crosstalk with ABA in an antagonistic manner via regulating root and shoot growth under drought [178]. Upon abiotic stress, along with ROS such as drought, inositol phosphate is produced, resulting in enhanced endogenous ABA levels [179]. Crosstalk between ABA and SA assists plantwater budget, osmotic adjustment, stomatal conductance, distribution of photoassimilates, and leaf senescence [178]. The expression of ERF1 (ethylene response factor1) is rapidly induced by ET and JA individually or synergistically [180]. Overexpression of ERF1 encourages drought tolerance and increases the accumulation of ABA levels and Pro, which restrict water loss and significantly contribute to stress resistance [181]. ERF1 activates the expression of LEA4-5 (late-embryogenesis abundant protein4-5) thereby resulting in drought tolerance (Figure 4) [182].

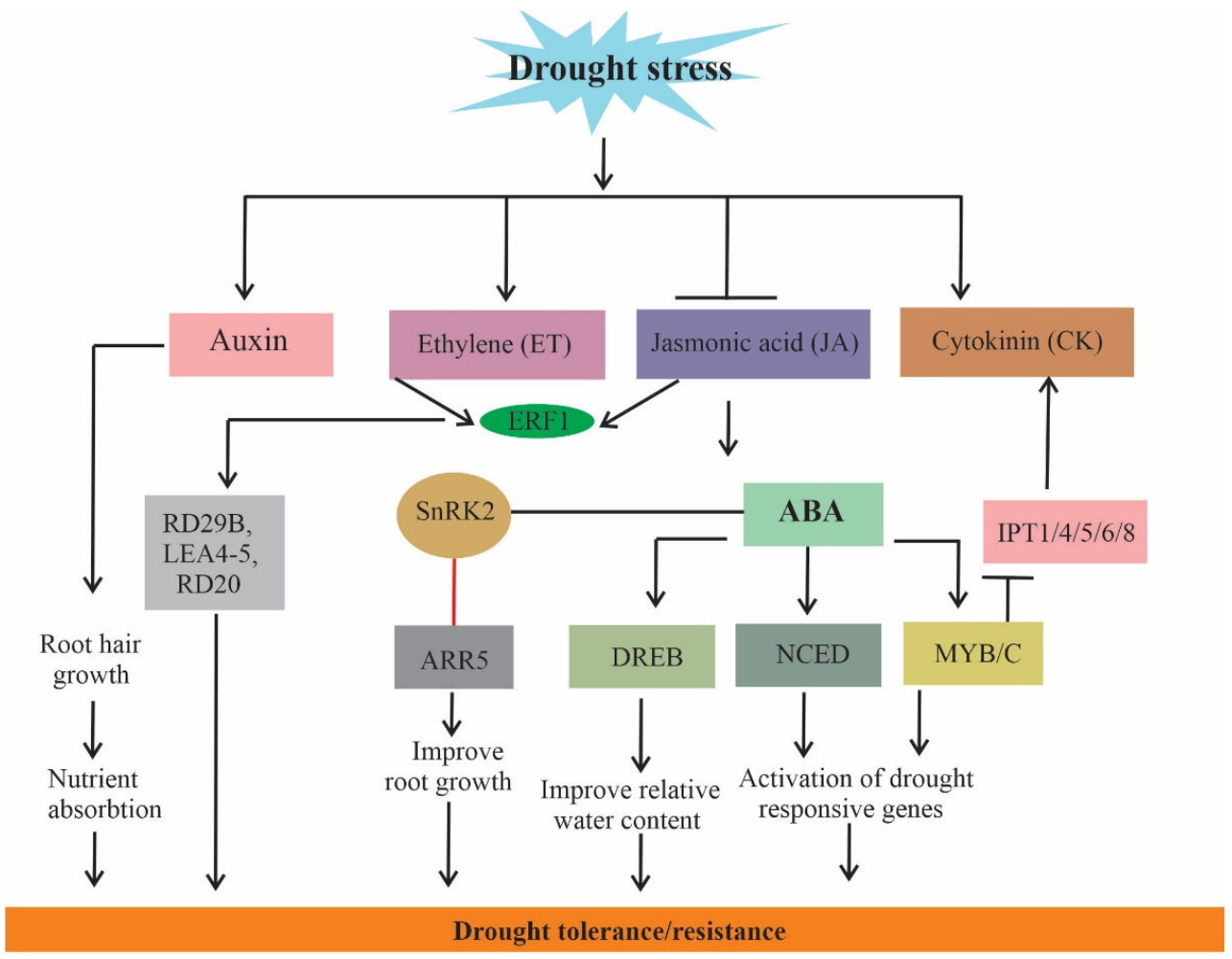

Figure 4. Proposed model of auxin, ethylene (ET), jasmonic acid (JA), cytokinin (CK), and ABA cross talk under drought stress. ERF1 (ETHYLENE RESPONSE FACTOR1) modulates expression of 
potential genes involved in drought tolerance. ABA-responsive component SnRK2, directly phosphorylates type-A RR5 (ARR5), ABA activates several transcription factors (TFs) which could result in enhanced drought tolerance.

\section{Other Related Mechanisms}

Several studies on drought have shown that the ABA hormone has a significant role in regulating the biochemical mechanisms that enable drought-prone plants to rapidly grow, flower, and produce mature seeds just before the onset of drought. Hwang et al. [183] confirmed that ABA plays an important role in regulating flowering during accelerated floral transition in $A$. thaliana. The study further showed that ABA-binding factors, ABF3 and ABF4 in A. thaliana enhance flowering by inducing SOC1 transcription, thus enabling the plant to complete its lifecycle under drought stress [183].

Besides ABA hormone responses, plants possess other ABA-independent mechanisms through which they mitigate drought effects [184]. The role of nutritional stress in drought stress alleviation remains a key area of focus. Drought normally results in depleted nutrients which lead to poor plant growth and development, and finally low crop yields. Studies have shown that plants associated with high nutrient use efficiency can ameliorate stress effects and cope with drought $[185,186]$. Micro and macronutrients including phosphorus [187], calcium [188], potassium [189], nitrogen [190], silicon [191], magnesium, and zinc [192] were reported to help in alleviating the adverse effects of drought. Although several studies have shown how different micro and macronutrients in plants are affected by drought, more research is needed to decipher the interactive mechanisms of these molecules with plants.

ABA-deficient mutant rice, however, induced low ABA and delayed flowering. The study reported some of the light receptors, circadian components, and genes related to flowering including $O s \mathrm{SOC}_{1}, \mathrm{Ghd}_{7}$, and PhyB involved in drought stress in an ABA-dependent manner. Several studies [183,193,194] have also reported ABA to modulate drought escape by activating the expression of florigen genes FT and TSP, and the floral integrator $S O C_{1}\left(\mathrm{ABF}_{3}\right.$ and $\left.\mathrm{ABF}_{4}\right)$ in Arabidopsis. Understanding the connection between ABA and drought escape is of importance in practical circumstances whereby crops are under irrigation, in such a scenario, the ABA responses could be targeted to ensure maximum crop production. The knowledge tapped from studies on drought escape mechanisms in plants needs to be utilized in developing drought-resistant crops that can easily withstand the dry seasons thus enhancing food production for the increasing world population (Figure 5).

Drought - at the early stage of plant development-could trigger early flowering and reduce tiller numbers by inducing the accumulation of ABA [195] by activating ABA signaling components that control water status and stomatal closure, promoting plant escape or adaptation to drought stress. Similarly, trehalose treatment upregulates ABA signaling-related gene expression via activating the ABA signaling pathway, regulating stomatal aperture, and preventing transpirational water loss [196]. It was reported that drought has feedback effects on the circadian clock by simultaneously regulating many flowering-related genes such as OsTOC1, Ghd7, OsGI, OsELF3, OsPRR37, OsMADS50, and PhyB, which promotes early flowering [195,197] in an ABA-dependent manner [195]. 


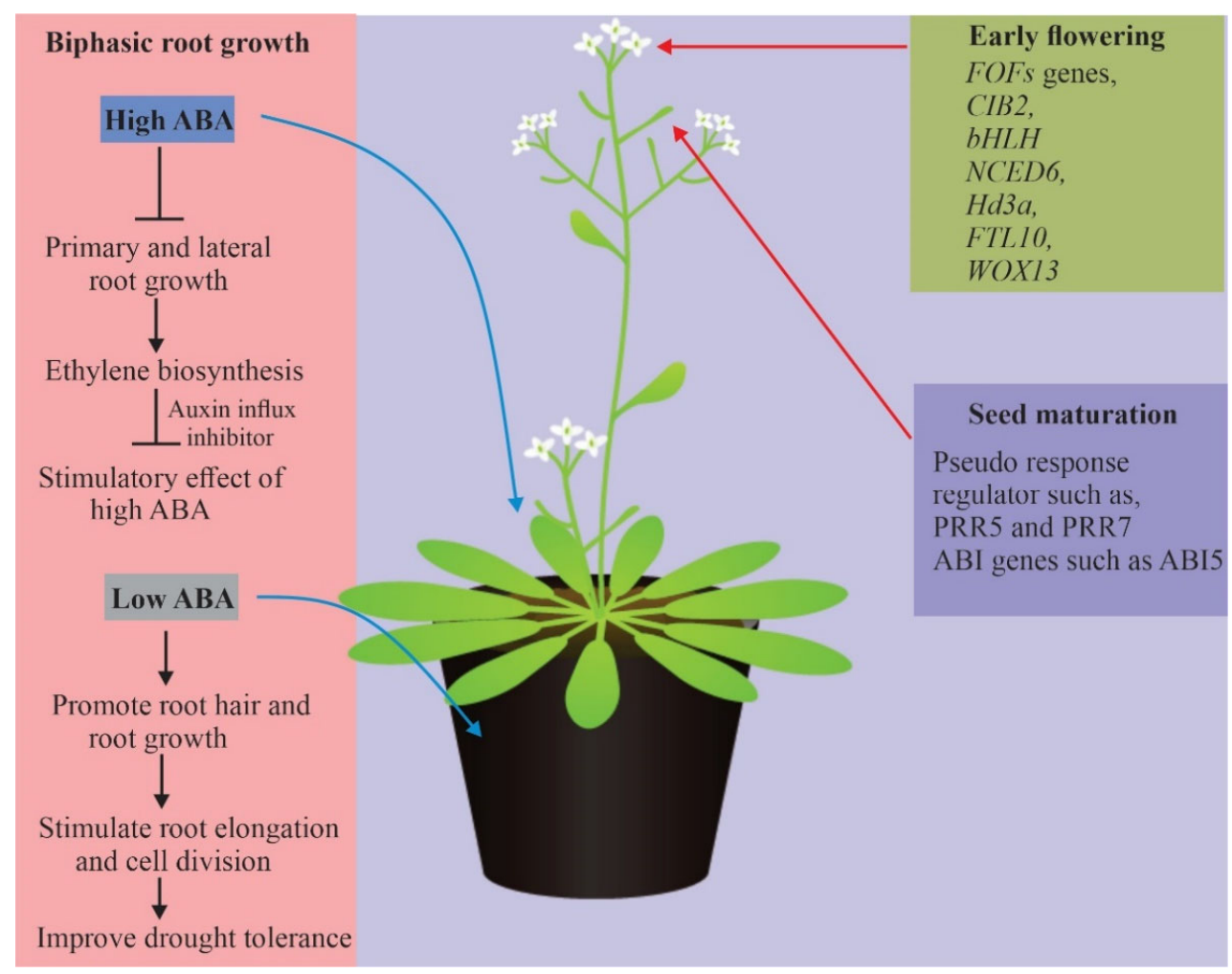

Figure 5. The molecular basis of ABA-mediated plant response to drought. A high concentration of ABA imposed a negative effect on auxin influx, while a low concentration of ABA promotes root growth resulted in enhanced drought tolerance.

\section{Conclusions and Perspective}

Environmental stresses, particularly drought, impair plant growth and productivity threatening global food security. Therefore, the development of drought-resistant crops is an important implication to sustainable crop production. Plants have evolved a series of adaptive strategies at cellular and molecular levels to cope with environmental cues including drought. The underlying genetic and molecular mechanisms of drought tolerance and escape are still an emerging topic in plant biology. Drought escape is the adaptive mechanism through which plants undergo rapid development to complete their life cycle before the onset of serious water deficits [198]. ABA is a key hormone and critical regulator of different stresses, including drought and salinity in various plant species. The overall progress of research on ABA-mediated drought responses has revealed its key role in growth and development during stress conditions. However, how plants perceive and transmit drought stress to different cells to initiate ABA accumulation for drought resistance remains unclear.

ABA receptors are present in almost every tissue and expressed specifically in each tissue allowing the plant to sense environmental signals and transmit them accurately to the target tissues. ABA regulates many aspects of plant growth, development, regulation of stomatal closure, channel activities in guard cells, promoting proline synthesis and accumulation, transcription of calmodulin protein, accelerated floral transition and seed maturation, and expression of ABA-drought responsive genes [199-201]. To achieve this, various drought-responsive genes and metabolic pathways are triggered leading to beneficial adjustments in the morphological structures and growth rate [86].

Various regulatory factors complement cell-to-cell or tissue-to-tissue communication and long-distance translocation from tissues for synthesis to target tissues. Recently, advances have been made in understanding the ABA regulatory mechanism at the molecular and cellular levels providing novel insights for biotechnology and agriculture merits for further research for crop breeding programs and crop innovation. Moreover, integrated 
phenomics will be key in addition to other high-throughput approaches to assess plant phenotype against drought stress. Similarly, artificial intelligence and machine learning are powerful techniques to understand these complex integrated systems in plant responses to drought.

Author Contributions: W.Y. and Q.Z. contributed in funding acquisition; M.M.A., M.W. and Q.Z. designed the manuscript; M.W., M.M.A., B.H.J. and E.J.O. wrote the first draft; M.M.A. and M.W. designed the diagrams; Q.Z., W.X., H.S.A.S., Z.L. and W.Y. reviewed and approved the final manuscript. All authors have read and agreed to the published version of the manuscript.

Funding: We are grateful for grants support from the Science and Technology Projects of China National Tobacco Corporation Fujian Company (2021350000240014), Fujian Province Natural Science Foundation (2020J01553) and the Education Department of Fujian Province (JAT190134).

Institutional Review Board Statement: Not applicable.

Informed Consent Statement: Not applicable.

Data Availability Statement: All data were available within the manuscript.

Conflicts of Interest: The authors declare no conflict of interest.

\section{References}

1. Rubin, R.L.; van Groenigen, K.J.; Hungate, B.A. Plant growth promoting rhizobacteria are more effective under drought: A meta-analysis. Plant Soil 2017, 416, 309-323. [CrossRef]

2. Ali, S.; Hayat, K.; Iqbal, A.; Xie, L. Implications of Abscisic Acid in the Drought Stress Tolerance of Plants. Agronomy 2020, 10, 1323. [CrossRef]

3. Müller, M. Foes or friends: ABA and ethylene interaction under abiotic stress. Plants 2021, 10, 448. [CrossRef] [PubMed]

4. Wani, S.H.; Kumar, V. Plant stress tolerance: Engineering ABA: A potent phytohormone. Transcriptomics 2015, 3, 1000113. [CrossRef]

5. $\quad$ Chaves, M.M.; Maroco, J.P.; Pereira, J.S. Understanding plant responses to drought-from genes to the whole plant. Funct. Plant Biol. FPB 2003, 30, 239-264. [CrossRef]

6. Gonzalez-Villagra, J.; Figueroa, C.; Luengo-Escobar, A.; Morales, M.; Inostroza-Blancheteau, C.; Reyes-Díaz, M. Abscisic Acid and Plant Response under Adverse Environmental Conditions. In Plant Performance under Environmental Stress; Springer: Berlin/Heidelberg, Germany, 2021; pp. 17-47.

7. Trivedi, D.K.; Gill, S.S.; Tuteja, N. Abscisic acid (ABA): Biosynthesis, regulation, and role in abiotic stress tolerance. Abiotic Stress Response Plants 2016, 8, 315-326.

8. Dejonghe, W.; Okamoto, M.; Cutler, S.R. Small molecule probes of ABA biosynthesis and signaling. Plant Cell Physiol. 2018, 59, 1490-1499. [CrossRef] [PubMed]

9. Vishwakarma, K.; Upadhyay, N.; Kumar, N.; Yadav, G.; Singh, J.; Mishra, R.K.; Kumar, V.; Verma, R.; Upadhyay, R.G.; Pandey, M.; et al. Abscisic Acid Signaling and Abiotic Stress Tolerance in Plants: A Review on Current Knowledge and Future Prospects. Front. Plant Sci. 2017, 8, 161. [CrossRef]

10. Kim, T.-H.; Böhmer, M.; Hu, H.; Nishimura, N.; Schroeder, J.I. Guard cell signal transduction network: Advances in understanding abscisic acid, CO2, and Ca2+ signaling. Annu. Rev. Plant Biol. 2010, 61, 561-591. [CrossRef]

11. Dar, N.A.; Amin, I.; Wani, W.; Wani, S.A.; Shikari, A.B.; Wani, S.H.; Masoodi, K.Z. Abscisic acid: A key regulator of abiotic stress tolerance in plants. Plant Gene 2017, 11, 106-111. [CrossRef]

12. Verma, V.; Ravindran, P.; Kumar, P.P. Plant hormone-mediated regulation of stress responses. BMC Plant Biol. 2016, 16, 1-10. [CrossRef] [PubMed]

13. Boominathan, P.; Shukla, R.; Kumar, A.; Manna, D.; Negi, D.; Verma, P.K.; Chattopadhyay, D. Long term transcript accumulation during the development of dehydration adaptation in Cicer arietinum. Plant Physiol. 2004, 135, 1608-1620. [CrossRef] [PubMed]

14. Zhu, J.-K. Salt and drought stress signal transduction in plants. Annu. Rev. Plant Biol. 2002, 53, 247-273. [CrossRef] [PubMed]

15. Zhang, H.; Zhu, H.; Pan, Y.; Yu, Y.; Luan, S.; Li, L. A DTX/MATE-type transporter facilitates abscisic acid efflux and modulates ABA sensitivity and drought tolerance in Arabidopsis. Mol. Plant 2014, 7, 1522-1532. [CrossRef] [PubMed]

16. Saavedra, X.; Modrego, A.; Rodriưguez, D.; Gonzaủlez-Garcưa, M.P.; Sanz, L.; Nicolaưs, G.; Lorenzo, O. The nuclear interactor PYL8/RCAR3 of Fagus sylvatica FsPP2C1 is a positive regulator of abscisic acid signaling in seeds and stress. Plant Physiol. 2010, 152, 133-150. [CrossRef] [PubMed]

17. Zhang, X.; Wollenweber, B.; Jiang, D.; Liu, F.; Zhao, J. Water deficits and heat shock effects on photosynthesis of a transgenic Arabidopsis thaliana constitutively expressing ABP9, a bZIP transcription factor. J. Exp. Bot. 2008, 59, 839-848. [CrossRef]

18. Sridha, S.; Wu, K. Identification of AtHD2C as a novel regulator of abscisic acid responses in Arabidopsis. Plant J. 2006, 46, 124-133. [CrossRef] 
19. Hamel, L.-P.; Nicole, M.-C.; Duplessis, S.; Ellis, B.E. Mitogen-activated protein kinase signaling in plant-interacting fungi: Distinct messages from conserved messengers. Plant Cell 2012, 24, 1327-1351. [CrossRef]

20. Muchhal, U.S.; Raghothama, K.G. Transcriptional regulation of plant phosphate transporters. Proc. Natl. Acad. Sci. USA 1999, 96, 5868-5872. [CrossRef]

21. Daszkowska-Golec, A. The role of abscisic acid in drought stress: How aba helps plants to cope with drought stress. In Drought Stress Tolerance in Plants; Springer: Berlin/Heidelberg, Germany, 2016; Volume 2, pp. 123-151.

22. Fujii, H.; Zhu, J.-K. Arabidopsis mutant deficient in 3 abscisic acid-activated protein kinases reveals critical roles in growth, reproduction, and stress. Proc. Natl. Acad. Sci. USA 2009, 106, 8380-8385. [CrossRef]

23. Umezawa, T.; Sugiyama, N.; Mizoguchi, M.; Hayashi, S.; Myouga, F.; Yamaguchi-Shinozaki, K.; Ishihama, Y.; Hirayama, T.; Shinozaki, K. Type 2C protein phosphatases directly regulate abscisic acid-activated protein kinases in Arabidopsis. Proc. Natl. Acad. Sci. USA 2009, 106, 17588-17593. [CrossRef] [PubMed]

24. Vlad, F.; Rubio, S.; Rodrigues, A.; Sirichandra, C.; Belin, C.; Robert, N.; Leung, J.; Rodriguez, P.L.; Laurière, C.; Merlot, S. Protein phosphatases 2C regulate the activation of the Snf1-related kinase OST1 by abscisic acid in Arabidopsis. Plant Cell 2009, 21, 3170-3184. [CrossRef] [PubMed]

25. González-Guzmán, M.; Rodríguez, L.; Lorenzo-Orts, L.; Pons, C.; Sarrión-Perdigones, A.; Fernández, M.A.; Peirats-Llobet, M.; Forment, J.; Moreno-Alvero, M.; Cutler, S.R. Tomato PYR/PYL/RCAR abscisic acid receptors show high expression in root, differential sensitivity to the abscisic acid agonist quinabactin, and the capability to enhance plant drought resistance. J. Exp. Bot. 2014, 65, 4451-4464. [CrossRef] [PubMed]

26. Kim, H.; Lee, K.; Hwang, H.; Bhatnagar, N.; Kim, D.-Y.; Yoon, I.S.; Byun, M.-O.; Kim, S.T.; Jung, K.-H.; Kim, B.-G. Overexpression of PYL5 in rice enhances drought tolerance, inhibits growth, and modulates gene expression. J. Exp. Bot. 2014, 65, 453-464. [CrossRef] [PubMed]

27. Okamoto, M.; Peterson, F.C.; Defries, A.; Park, S.-Y.; Endo, A.; Nambara, E.; Volkman, B.F.; Cutler, S.R. Activation of dimeric ABA receptors elicits guard cell closure, ABA-regulated gene expression, and drought tolerance. Proc. Natl. Acad. Sci. USA 2013, 110, 12132-12137. [CrossRef]

28. Pizzio, G.A.; Rodriguez, L.; Antoni, R.; Gonzalez-Guzman, M.; Yunta, C.; Merilo, E.; Kollist, H.; Albert, A.; Rodriguez, P.L. The PYL4 A194T mutant uncovers a key role of PYR1-LIKE4/PROTEIN PHOSPHATASE 2CA interaction for abscisic acid signaling and plant drought resistance. Plant Physiol. 2013, 163, 441-455. [CrossRef]

29. Zhang, H.; Liu, D.; Yang, B.; Liu, W.Z.; Mu, B.; Song, H.; Chen, B.; Li, Y.; Ren, D.; Deng, H.; et al. Arabidopsis CPK6 positively regulates $\mathrm{ABA}$ signaling and drought tolerance through phosphorylating ABA-responsive element-binding factors. J. Exp. Bot. 2020, 71, 188-203. [CrossRef]

30. Park, H.-Y.; Seok, H.-Y.; Park, B.-K.; Kim, S.-H.; Goh, C.-H.; Lee, B.-h.; Lee, C.-H.; Moon, Y.-H. Overexpression of Arabidopsis ZEP enhances tolerance to osmotic stress. Biochem. Biophys. Res. Commun. 2008, 375, 80-85. [CrossRef]

31. Lu, G.; Gao, C.; Zheng, X.; Han, B. Identification of OsbZIP72 as a positive regulator of ABA response and drought tolerance in rice. Planta 2009, 229, 605-615. [CrossRef]

32. Kang, J.; Hwang, J.-U.; Lee, M.; Kim, Y.-Y.; Assmann, S.M.; Martinoia, E.; Lee, Y. PDR-type ABC transporter mediates cellular uptake of the phytohormone abscisic acid. Proc. Natl. Acad. Sci. USA 2010, 107, 2355-2360. [CrossRef]

33. Chen, K.; Li, G.J.; Bressan, R.A.; Song, C.P.; Zhu, J.K.; Zhao, Y. Abscisic acid dynamics, signaling, and functions in plants. J. Integr. Plant Biol. 2020, 62, 25-54. [CrossRef] [PubMed]

34. Yu, Y.; Wang, P.; Bai, Y.; Wang, Y.; Wan, H.; Liu, C.; Ni, Z. The soybean F-box protein GmFBX176 regulates ABA-mediated responses to drought and salt stress. Environ. Exp. Bot. 2020, 176, 104056. [CrossRef]

35. Zhang, J.; Jia, W.; Yang, J.; Ismail, A.M. Role of ABA in integrating plant responses to drought and salt stresses. Field Crops Res. 2006, 97, 111-119. [CrossRef]

36. Dossa, K.; Mmadi, M.A.; Zhou, R.; Liu, A.; Yang, Y.; Diouf, D.; You, J.; Zhang, X. Ectopic expression of the sesame MYB transcription factor SiMYB305 promotes root growth and modulates ABA-mediated tolerance to drought and salt stresses in Arabidopsis. AoB Plants 2019, 12, plz081. [CrossRef] [PubMed]

37. Wang, L.; Zhu, J.; Li, X.; Wang, S.; Wu, J. Salt and drought stress and ABA responses related to bZIP genes from V. radiata and V. angularis. Gene 2018, 651, 152-160. [CrossRef] [PubMed]

38. Baek, D.; Chun, H.J.; Kang, S.; Shin, G.; Park, S.J.; Hong, H.; Kim, C.; Kim, D.H.; Lee, S.Y.; Kim, M.C. A role for Arabidopsis miR399f in salt, drought, and ABA signaling. Mol. Cells 2016, 39, 111.

39. Seleiman, M.F.; Al-Suhaibani, N.; Ali, N.; Akmal, M.; Alotaibi, M.; Refay, Y.; Dindaroglu, T.; Abdul-Wajid, H.H.; Battaglia, M.L. Drought stress impacts on plants and different approaches to alleviate its adverse effects. Plants 2021, 10, 259. [CrossRef]

40. Sreenivasulu, N.; Harshavardhan, V.T.; Govind, G.; Seiler, C.; Kohli, A. Contrapuntal role of ABA: Does it mediate stress tolerance or plant growth retardation under long-term drought stress? Gene 2012, 506, 265-273. [CrossRef]

41. Cruz de Carvalho, M.H. Drought stress and reactive oxygen species: Production, scavenging and signaling. Plant Signal. Behav. 2008, 3, 156-165. [CrossRef]

42. Foyer, C.H.; Noctor, G. Redox homeostasis and antioxidant signaling: A metabolic interface between stress perception and physiological responses. Plant Cell 2005, 17, 1866-1875. [CrossRef]

43. Verslues, P.E.; Zhu, J.K. Before and beyond ABA: Upstream sensing and internal signals that determine ABA accumulation and response under abiotic stress. Biochem. Soc. Trans. 2005, 33, 375-379. [CrossRef] [PubMed] 
44. Li, X.; Chen, L.; Forde, B.G.; Davies, W.J. The Biphasic Root Growth Response to Abscisic Acid in Arabidopsis Involves Interaction with Ethylene and Auxin Signalling Pathways. Front. Plant Sci. 2017, 8, 1493. [CrossRef] [PubMed]

45. Zhou, Y.; He, R.; Guo, Y.; Liu, K.; Huang, G.; Peng, C.; Liu, Y.; Zhang, M.; Li, Z.; Duan, L. A novel ABA functional analogue B2 enhances drought tolerance in wheat. Sci. Rep. 2019, 9, 2887. [CrossRef] [PubMed]

46. Sharp, R.E.; Poroyko, V.; Hejlek, L.G.; Spollen, W.G.; Springer, G.K.; Bohnert, H.J.; Nguyen, H.T. Root growth maintenance during water deficits: Physiology to functional genomics. J Exp. Bot. 2004, 55, 2343-2351. [CrossRef] [PubMed]

47. Wu, Y.; Thorne, E.T.; Sharp, R.E.; Cosgrove, D.J. Modification of expansin transcript levels in the maize primary root at low water potentials. Plant Physiol. 2001, 126, 1471-1479. [CrossRef]

48. Kwak, J.M.; Mori, I.C.; Pei, Z.M.; Leonhardt, N.; Torres, M.A.; Dangl, J.L.; Bloom, R.E.; Bodde, S.; Jones, J.D.; Schroeder, J.I. NADPH oxidase AtrbohD and AtrbohF genes function in ROS-dependent ABA signaling in Arabidopsis. EMBO J. 2003, 22, 2623-2633. [CrossRef]

49. Gilroy, S.; Read, N.; Trewavas, A.J. Elevation of cytoplasmic calcium by caged calcium or caged inositol trisphosphate initiates stomatal closure. Nature 1990, 346, 769-771. [CrossRef]

50. Aharoni, A.; Galili, G. Metabolic engineering of the plant primary-secondary metabolism interface. Curr. Opin. Biotechnol. 2011, 22, 239-244. [CrossRef]

51. Rausch, T.; Wachter, A. Sulfur metabolism: A versatile platform for launching defence operations. Trends Plant Sci. 2005, 10, 503-509. [CrossRef]

52. Kumar, M.; Patel, M.K.; Kumar, N.; Bajpai, A.B.; Siddique, K.H.M. Metabolomics and molecular approaches reveal drought stress tolerance in plants. Int. J. Mol. Sci. 2021, 22, 9108. [CrossRef]

53. Goodacre, R.; Vaidyanathan, S.; Dunn, W.B.; Harrigan, G.G.; Kell, D.B. Metabolomics by numbers: Acquiring and understanding global metabolite data. Trends Biotechnol. 2004, 22, 245-252. [CrossRef] [PubMed]

54. Zhu, M.; Assmann, S.M. Metabolic Signatures in Response to Abscisic Acid (ABA) Treatment in Brassica napus Guard Cells Revealed by Metabolomics. Sci. Rep. 2017, 7, 12875. [CrossRef] [PubMed]

55. Yoshida, T.; Obata, T.; Feil, R.; Lunn, J.E.; Fujita, Y.; Yamaguchi-Shinozaki, K.; Fernie, A.R. The role of abscisic acid signaling in maintaining the metabolic balance required for Arabidopsis growth under nonstress conditions. Plant Cell 2019, 31, 84-105. [CrossRef] [PubMed]

56. Dekkers, B.J.W.; Costa, M.C.D.; Maia, J.; Bentsink, L.; Ligterink, W.; Hilhorst, H.W.M. Acquisition and loss of desiccation tolerance in seeds: From experimental model to biological relevance. Planta 2015, 241, 563-577. [CrossRef]

57. Munemasa, S.; Hauser, F.; Park, J.; Waadt, R.; Brandt, B.; Schroeder, J.I. Mechanisms of abscisic acid-mediated control of stomatal aperture. Curr. Opin. Plant Biol. 2015, 28, 154-162. [CrossRef] [PubMed]

58. Nakashima, K.; Yamaguchi-Shinozaki, K. ABA signaling in stress-response and seed development. Plant Cell Rep. 2013, 32, 959-970. [CrossRef]

59. LeNoble, M.E.; Spollen, W.G.; Sharp, R.E. Maintenance of shoot growth by endogenous ABA: Genetic assessment of the involvement of ethylene suppression. J. Exp. Bot. 2004, 55, 237-245. [CrossRef]

60. Sharp, R.E.; LeNoble, M.E.; Else, M.A.; Thorne, E.T.; Gherardi, F. Endogenous ABA maintains shoot growth in tomato independently of effects on plant water balance: Evidence for an interaction with ethylene. J. Exp. Bot. 2000, 51, 1575-1584. [CrossRef]

61. Abdullah, H.M.; Rodriguez, J.; Salacup, J.M.; Castañeda, I.S.; Schnell, D.J.; Pareek, A.; Dhankher, O.P. Increased Cuticle Waxes by Overexpression of WSD1 Improves Osmotic Stress Tolerance in Arabidopsis thaliana and Camelina sativa. Int. J. Mol. Sci. 2021, 22, 5173. [CrossRef]

62. Zhu, M.; Simons, B.; Zhu, N.; Oppenheimer, D.G.; Chen, S. Analysis of abscisic acid responsive proteins in Brassica napus guard cells by multiplexed isobaric tagging. J. Proteom. 2010, 73, 790-805. [CrossRef]

63. Cramer, G.R.; Urano, K.; Delrot, S.; Pezzotti, M.; Shinozaki, K. Effects of abiotic stress on plants: A systems biology perspective. BMC Plant Biol. 2011, 11, 1-14. [CrossRef] [PubMed]

64. Sweetlove, L.J.; Fell, D.; Fernie, A.R. Getting to grips with the plant metabolic network. Biochem. J. 2008, 409, 27-41. [CrossRef] [PubMed]

65. Fiers, M.; Golemiec, E.; Xu, J.; van der Geest, L.; Heidstra, R.; Stiekema, W.; Liu, C.-M. The 14-amino acid CLV3, CLE19, and CLE40 peptides trigger consumption of the root meristem in Arabidopsis through a CLAVATA2-dependent pathway. Plant Cell 2005, 17, 2542-2553. [CrossRef] [PubMed]

66. Krasensky, J.; Jonak, C. Drought, salt, and temperature stress-induced metabolic rearrangements and regulatory networks. J. Exp. Bot. 2012, 63, 1593-1608. [CrossRef]

67. Dixon, R.A.; Paiva, N.L. Stress-induced phenylpropanoid metabolism. Plant Cell 1995, 7, 1085. [CrossRef]

68. Takahashi, F.; Kuromori, T.; Urano, K.; Yamaguchi-Shinozaki, K.; Shinozaki, K. Drought Stress Responses and Resistance in Plants: From Cellular Responses to Long-Distance Intercellular Communication. Front. Plant Sci. 2020, 11, 556972. [CrossRef]

69. Urano, K.; Maruyama, K.; Ogata, Y.; Morishita, Y.; Takeda, M.; Sakurai, N.; Suzuki, H.; Saito, K.; Shibata, D.; Kobayashi, M. Characterization of the ABA-regulated global responses to dehydration in Arabidopsis by metabolomics. Plant J. 2009, 57, 1065-1078. [CrossRef] 
70. Pires, M.V.; Pereira Júnior, A.A.; Medeiros, D.B.; Daloso, D.M.; Pham, P.A.; Barros, K.A.; Engqvist, M.K.M.; Florian, A.; Krahnert, I.; Maurino, V.G. The influence of alternative pathways of respiration that utilize branched-chain amino acids following water shortage in Arabidopsis. Plant Cell Environ. 2016, 39, 1304-1319. [CrossRef]

71. Tarazona, P.; Feussner, K.; Feussner, I. An enhanced plant lipidomics method based on multiplexed liquid chromatography-mass spectrometry reveals additional insights into cold-and drought-induced membrane remodeling. Plant J. 2015, 84, 621-633. [CrossRef]

72. Nakabayashi, R.; Mori, T.; Saito, K. Alternation of flavonoid accumulation under drought stress in Arabidopsis thaliana. Plant Signal. Behav. 2014, 9, e29518. [CrossRef]

73. Ma, X.; Xia, H.; Liu, Y.; Wei, H.; Zheng, X.; Song, C.; Chen, L.; Liu, H.; Luo, L. Transcriptomic and metabolomic studies disclose key metabolism pathways contributing to well-maintained photosynthesis under the drought and the consequent drought-tolerance in rice. Front. Plant Sci. 2016, 7, 1886. [CrossRef] [PubMed]

74. Obata, T.; Witt, S.; Lisec, J.; Palacios-Rojas, N.; Florez-Sarasa, I.; Yousfi, S.; Araus, J.L.; Cairns, J.E.; Fernie, A.R. Metabolite profiles of maize leaves in drought, heat, and combined stress field trials reveal the relationship between metabolism and grain yield Plant Physiol. 2015, 169, 2665-2683. [CrossRef] [PubMed]

75. Chmielewska, K.; Rodziewicz, P.; Swarcewicz, B.; Sawikowska, A.; Krajewski, P.; Marczak, Ł.; Ciesiołka, D.; Kuczyńska, A.; Mikołajczak, K.; Ogrodowicz, P. Analysis of drought-induced proteomic and metabolomic changes in barley (Hordeum vulgare L.) leaves and roots unravels some aspects of biochemical mechanisms involved in drought tolerance. Front. Plant Sci. 2016, 7 , 1108. [CrossRef] [PubMed]

76. Liu, X.; Zhai, S.; Zhao, Y.; Sun, B.; Liu, C.; Yang, A.; Zhang, J. Overexpression of the phosphatidylinositol synthase gene (ZmPIS) conferring drought stress tolerance by altering membrane lipid composition and increasing ABA synthesis in maize. Plant Cell Environ. 2013, 36, 1037-1055. [CrossRef]

77. Nam, K.-H.; Kim, H.J.; Pack, I.-S.; Kim, H.J.; Chung, Y.S.; Kim, S.Y.; Kim, C.-G. Global metabolite profiling based on GC-MS and LC-MS/MS analyses in ABF3-overexpressing soybean with enhanced drought tolerance. Appl. Biol. Chem. 2019, 62, 1-9. [CrossRef]

78. Hong, J.H.; Seah, S.W.; Xu, J. The root of ABA action in environmental stress response. Plant Cell Rep. 2013, 32, 971-983. [CrossRef] [PubMed]

79. Benderradji, L.; Saibi, W.; Brini, F. Role of ABA in Overcoming Environmental Stress: Sensing, Signaling and Crosstalk. Annu. Agric. Crop Sci. 2021, 6, 1070.

80. Liang, Y.; Mitchell, D.M.; Harris, J.M. Abscisic acid rescues the root meristem defects of the Medicago truncatula latd mutant. Dev. Biol. 2007, 304, 297-307. [CrossRef]

81. De Smet, I.; Signora, L.; Beeckman, T.; Inzé, D.; Foyer, C.H.; Zhang, H. An abscisic acid-sensitive checkpoint in lateral root development of Arabidopsis. Plant J. 2003, 33, 543-555. [CrossRef]

82. Deak, K.I.; Malamy, J. Osmotic regulation of root system architecture. Plant J. 2005, 43, 17-28. [CrossRef]

83. Guo, D.; Liang, J.; Qiao, Y.; Yan, Y.; Li, L.; Dai, Y. Involvement of G1-to-S transition and AhAUX-dependent auxin transport in abscisic acid-induced inhibition of lateral root primodia initiation in Arachis hypogaea L. J. Plant Physiol. 2012, 169, $1102-1111$. [CrossRef] [PubMed]

84. Quiroz-Figueroa, F.; Rodríguez-Acosta, A.; Salazar-Blas, A.; Hernández-Domínguez, E.; Campos, M.E.; Kitahata, N.; Asami, T.; Galaz-Avalos, R.M.; Cassab, G.I. Accumulation of high levels of ABA regulates the pleiotropic response of the nhr1 Arabidopsis mutant. J. Plant Biol. 2010, 53, 32-44. [CrossRef]

85. Zhang, C.; Bousquet, A.; Harris, J.M. Abscisic acid and lateral root organ defective/modulate root elongation via reactive oxygen species in Medicago truncatula. Plant Physiol. 2014, 166, 644-658. [CrossRef] [PubMed]

86. Fang, Y.; Xiong, L. General mechanisms of drought response and their application in drought resistance improvement in plants. Cell. Mol. Life Sci. 2015, 72, 673-689. [CrossRef]

87. Zhang, Q.; Yuan, W.; Wang, Q.; Cao, Y.; Xu, F.; Dodd, I.C.; Xu, W. ABA regulation of root growth during soil drying and recovery can involve auxin response. Plant Cell Environ. 2021. [CrossRef]

88. Sharp, R.E.; LeNoble, M.E. ABA, ethylene and the control of shoot and root growth under water stress. J. Exp. Bot. 2002, 53, 33-37. [CrossRef]

89. Williams, A.; de Vries, F.T. Plant root exudation under drought: Implications for ecosystem functioning. New Phytol. 2020, 225, 1899-1905. [CrossRef]

90. Lynch, J.M.; Whipps, J.M. Substrate flow in the rhizosphere. Plant Soil 1990, 129, 1-10. [CrossRef]

91. Badri, D.V.; Vivanco, J.M. Regulation and function of root exudates. Plant Cell Environ. 2009, 32, 666-681. [CrossRef]

92. Baetz, U.; Martinoia, E. Root exudates: The hidden part of plant defense. Trends Plant Sci. 2014, 19, 90-98. [CrossRef]

93. Rudrappa, T.; Czymmek, K.J.; Paré, P.W.; Bais, H.P. Root-Secreted Malic Acid Recruits Beneficial Soil Bacteria. Plant Physiol. 2008, 148, 1547-1556. [CrossRef]

94. Iannucci, A.; Fragasso, M.; Platani, C.; Papa, R. Plant growth and phenolic compounds in the rhizosphere soil of wild oat (Avena fatua L.). Front. Plant Sci. 2013, 4, 509. [CrossRef]

95. Zhalnina, K.; Louie, K.B.; Hao, Z.; Mansoori, N.; da Rocha, U.N.; Shi, S.; Cho, H.; Karaoz, U.; Loqué, D.; Bowen, B.P. Dynamic root exudate chemistry and microbial substrate preferences drive patterns in rhizosphere microbial community assembly. Nat. Microbiol. 2018, 3, 470-480. [CrossRef] 
96. Williams, A.; Langridge, H.; Straathof, A.L.; Muhamadali, H.; Hollywood, K.A.; Goodacre, R.; de Vries, F.T. Root functional traits explain root exudation rate and composition across a range of grassland species. J. Ecol. 2021, 110, 21-33. [CrossRef]

97. Dennis, P.G.; Miller, A.J.; Hirsch, P.R. Are root exudates more important than other sources of rhizodeposits in structuring rhizosphere bacterial communities? FEMS Microbiol. Ecol. 2010, 72, 313-327. [CrossRef]

98. Naylor, D.; Coleman-Derr, D. Drought stress and root-associated bacterial communities. Front. Plant Sci. 2018, 8, 2223. [CrossRef]

99. Bulgarelli, D.; Schlaeppi, K.; Spaepen, S.; Van Themaat, E.V.L.; Schulze-Lefert, P. Structure and functions of the bacterial microbiota of plants. Annu. Rev. Plant Biol. 2013, 64, 807-838. [CrossRef] [PubMed]

100. De Ollas, C.; Arbona, V.; GóMez-Cadenas, A. Jasmonoyl isoleucine accumulation is needed for abscisic acid build-up in roots of A rabidopsis under water stress conditions. Plant Cell Environ. 2015, 38, 2157-2170. [CrossRef]

101. Yang, J.; Zhang, J.; Wang, Z.; Zhu, Q.; Liu, L. Abscisic acid and cytokinins in the root exudates and leaves and their relationship to senescence and remobilization of carbon reserves in rice subjected to water stress during grain filling. Planta 2002, 215, 645-652. [CrossRef]

102. Song, F.; Han, X.; Zhu, X.; Herbert, S.J. Response to water stress of soil enzymes and root exudates from drought and non-drought tolerant corn hybrids at different growth stages. Can. J. Soil Sci. 2012, 92, 501-507. [CrossRef]

103. Gargallo-Garriga, A.; Preece, C.; Sardans, J.; Oravec, M.; Urban, O.; Peñuelas, J. Root exudate metabolomes change under drought and show limited capacity for recovery. Sci. Rep. 2018, 8, 12696. [CrossRef] [PubMed]

104. Porcel, R.; Zamarreño, Á.M.; García-Mina, J.M.; Aroca, R. Involvement of plant endogenous ABA in Bacillus megaterium PGPR activity in tomato plants. BMC Plant Biol. 2014, 14, 36. [CrossRef] [PubMed]

105. Karadeniz, A.; Topcuoğlu, S..; Inan, S. Auxin, gibberellin, cytokinin and abscisic acid production in some bacteria. World J. Microbiol. Biotechnol. 2006, 22, 1061-1064. [CrossRef]

106. Kai, M.; Vespermann, A.; Piechulla, B. The growth of fungi and Arabidopsis thaliana is influenced by bacterial volatiles. Plant Signal. Behav. 2008, 3, 482-484. [CrossRef] [PubMed]

107. Nakayama, T.; Homma, Y.; Hashidoko, Y.; Mizutani, J.; Tahara, S. Possible role of xanthobaccins produced by Stenotrophomonas sp. strain SB-K88 in suppression of sugar beet damping-off disease. Appl. Environ. Microbiol. 1999, 65, 4334-4339. [CrossRef] [PubMed]

108. Henry, A.; Doucette, W.; Norton, J.; Bugbee, B. Changes in crested wheatgrass root exudation caused by flood, drought, and nutrient stress. J. Environ. Qual. 2007, 36, 904-912. [CrossRef] [PubMed]

109. Gagné-Bourque, F.; Bertrand, A.; Claessens, A.; Aliferis, K.A.; Jabaji, S. Alleviation of drought stress and metabolic changes in timothy (Phleum pratense L.) colonized with Bacillus subtilis B26. Front. Plant Sci. 2016, 7, 584. [CrossRef]

110. Sánchez-Fernández, D.; Rizzo, V.; Bourdeau, C.; Cieslak, A.; Comas, J.; Faille, A.; Fresneda, J.; Lleopart, E.; Millán, A.; Montes, A. The deep subterranean environment as a potential model system in ecological, biogeographical and evolutionary research. Subterr. Biol. 2018, 25, 1-7. [CrossRef]

111. Dodd, I.C.; Zinovkina, N.Y.; Safronova, V.I.; Belimov, A.A. Rhizobacterial mediation of plant hormone status. Ann. Appl. Biol. 2010, 157, 361-379. [CrossRef]

112. Belimov, A.A.; Dodd, I.C.; Safronova, V.I.; Dumova, V.A.; Shaposhnikov, A.I.; Ladatko, A.G.; Davies, W.J. Abscisic acid metabolizing rhizobacteria decrease ABA concentrations in planta and alter plant growth. Plant Physiol. Biochem. 2014, 74, 84-91. [CrossRef]

113. Gowtham, H.G.; Duraivadivel, P.; Ayusman, S.; Sayani, D.; Gholap, S.L.; Niranjana, S.R.; Hariprasad, P. ABA analogue produced by Bacillus marisflavi modulates the physiological response of Brassica juncea L. under drought stress. Appl. Soil Ecol. 2021, 159, 103845. [CrossRef]

114. Luo, X.; Chen, Z.; Gao, J.; Gong, Z. Abscisic acid inhibits root growth in Arabidopsis through ethylene biosynthesis. Plant J. Cell Mol. Biol. 2014, 79, 44-55. [CrossRef]

115. Fujita, Y.; Nakashima, K.; Yoshida, T.; Katagiri, T.; Kidokoro, S.; Kanamori, N.; Umezawa, T.; Fujita, M.; Maruyama, K.; Ishiyama, K.; et al. Three SnRK2 protein kinases are the main positive regulators of abscisic acid signaling in response to water stress in Arabidopsis. Plant Cell Physiol. 2009, 50, 2123-2132. [CrossRef]

116. Liu, X.; Yue, Y.; Li, B.; Nie, Y.; Li, W.; Wu, W.H.; Ma, L. A G protein-coupled receptor is a plasma membrane receptor for the plant hormone abscisic acid. Science 2007, 315, 1712-1716. [CrossRef]

117. Hirayama, T.; Shinozaki, K. Perception and transduction of abscisic acid signals: Keys to the function of the versatile plant hormone ABA. Trends Plant Sci. 2007, 12, 343-351. [CrossRef]

118. Kuromori, T.; Seo, M.; Shinozaki, K. ABA Transport and Plant Water Stress Responses. Trends Plant Sci. 2018, 23, 513-522. [CrossRef]

119. Merilo, E.; Jalakas, P.; Laanemets, K.; Mohammadi, O.; Hõrak, H.; Kollist, H.; Brosché, M. Abscisic Acid Transport and Homeostasis in the Context of Stomatal Regulation. Mol. Plant 2015, 8, 1321-1333. [CrossRef]

120. Zhang, A.; Ji, Y.; Sun, M.; Lin, C.; Zhou, P.; Ren, J.; Luo, D.; Wang, X.; Ma, C.; Zhang, X.; et al. Research on the drought tolerance mechanism of Pennisetum glaucum (L.) in the root during the seedling stage. BMC Genom. 2021, 22, 568. [CrossRef]

121. Li, X.; Yu, B.; Wu, Q.; Min, Q.; Zeng, R.; Xie, Z.; Huang, J. OsMADS23 phosphorylated by SAPK9 confers drought and salt tolerance by regulating ABA biosynthesis in rice. PLoS Genet. 2021, 17, e1009699. [CrossRef]

122. Mathan, J.; Singh, A.; Ranjan, A. Sucrose transport in response to drought and salt stress involves ABA-mediated induction of OsSWEET13 and OsSWEET15 in rice. Physiol. Plant. 2021, 171, 620-637. [CrossRef] 
123. Cao, L.; Lu, X.; Wang, G.; Zhang, Q.; Zhang, X.; Fan, Z.; Cao, Y.; Wei, L.; Wang, T.; Wang, Z. Maize ZmbZIP33 is involved in drought resistance and recovery ability through an abscisic acid-dependent signaling pathway. Front. Plant Sci. 2021, 12, 442. [CrossRef] [PubMed]

124. Aswath, C.R.; Kim, S.H.; Mo, S.Y.; Kim, D.H. Transgenic plants of creeping bent grass harboring the stress inducible gene, 9-cis-epoxycarotenoid dioxygenase, are highly tolerant to drought and NaCl stress. Plant Growth Regul. 2005, 47, 129-139. [CrossRef]

125. Zhang, Y.; Vasuki, H.; Liu, J.; Bar, H.; Lazary, S.; Egbaria, A.; Ripper, D.; Charrier, L.; Mussa, Z.; Wulff, N. ABA homeostasis and long-distance translocation is redundantly regulated by ABCG ABA importers. bioRxiv 2021, 7, eabf6069. [CrossRef] [PubMed]

126. Kanno, Y.; Hanada, A.; Chiba, Y.; Ichikawa, T.; Nakazawa, M.; Matsui, M.; Koshiba, T.; Kamiya, Y.; Seo, M. Identification of an abscisic acid transporter by functional screening using the receptor complex as a sensor. Proc. Natl. Acad. Sci. USA 2012, 109, 9653-9658. [CrossRef]

127. Huque, A.K.M.; So, W.; Noh, M.; You, M.K.; Shin, J.S. Overexpression of AtBBD1, Arabidopsis Bifunctional Nuclease, Confers Drought Tolerance by Enhancing the Expression of Regulatory Genes in ABA-Mediated Drought Stress Signaling. Int. J. Mol. Sci. 2021, 22, 2936. [CrossRef]

128. He, Y.; Liu, Y.; Li, M.; Lamin-Samu, A.T.; Yang, D.; Yu, X.; Izhar, M.; Jan, I.; Ali, M.; Lu, G. The Arabidopsis SMALL AUXIN UP RNA32 Protein Regulates ABA-Mediated Responses to Drought Stress. Front. Plant Sci. 2021, 12, 259. [CrossRef]

129. Le Hir, R.; Castelain, M.; Chakraborti, D.; Moritz, T.; Dinant, S.; Bellini, C. At bHLH68 transcription factor contributes to the regulation of ABA homeostasis and drought stress tolerance in Arabidopsis thaliana. Physiol. Plant. 2017, 160, 312-327. [CrossRef]

130. Baek, D.; Shin, G.; Kim, M.C.; Shen, M.; Lee, S.Y.; Yun, D.-J. Histone deacetylase HDA9 with ABI4 contributes to abscisic acid homeostasis in drought stress response. Front. Plant Sci. 2020, 11, 143. [CrossRef] [PubMed]

131. Kuromori, T.; Sugimoto, E.; Shinozaki, K. Brachypodium BdABCG25 is a homolog of Arabidopsis AtABCG25 involved in the transport of abscisic acid. FEBS Lett. 2021, 595, 954-959. [CrossRef]

132. Wang, Y.; Beaith, M.; Chalifoux, M.; Ying, J.; Uchacz, T.; Sarvas, C.; Griffiths, R.; Kuzma, M.; Wan, J.; Huang, Y. Shoot-specific down-regulation of protein farnesyltransferase ( $\alpha$-subunit) for yield protection against drought in canola. Mol. Plant 2009, 2, 191-200. [CrossRef]

133. Xu, M.; Li, H.; Liu, Z.-N.; Wang, X.-H.; Xu, P.; Dai, S.-J.; Cao, X.; Cui, X.-Y. The soybean CBL-interacting protein kinase, GmCIPK2, positively regulates drought tolerance and ABA signaling. Plant Physiol. Biochem. 2021, 167, 980-989. [CrossRef] [PubMed]

134. Zhang, Y.; Yang, J.; Lu, S.; Cai, J.; Guo, Z. Overexpressing SgNCED1 in tobacco increases ABA level, antioxidant enzyme activities, and stress tolerance. J. Plant Growth Regul. 2008, 27, 151-158. [CrossRef]

135. Zhang, S.; Haider, I.; Kohlen, W.; Jiang, L.; Bouwmeester, H.; Meijer, A.H.; Schluepmann, H.; Liu, C.-M.; Ouwerkerk, P.B.F. Function of the HD-Zip I gene Oshox22 in ABA-mediated drought and salt tolerances in rice. Plant Mol. Biol. 2012, 80, 571-585. [CrossRef] [PubMed]

136. Tang, N.; Zhang, H.; Li, X.; Xiao, J.; Xiong, L. Constitutive activation of transcription factor OsbZIP46 improves drought tolerance in rice. Plant Physiol. 2012, 158, 1755-1768. [CrossRef] [PubMed]

137. Yao, L.; Cheng, X.; Gu, Z.; Huang, W.; Li, S.; Wang, L.; Wang, Y.-F.; Xu, P.; Ma, H.; Ge, X. The AWPM-19 family protein OsPM1 mediates abscisic acid influx and drought response in rice. Plant Cell 2018, 30, 1258-1276. [CrossRef] [PubMed]

138. Estrada-Melo, A.C.; Chao, C.; Reid, M.S.; Jiang, C.-Z. Overexpression of an ABA biosynthesis gene using a stress-inducible promoter enhances drought resistance in petunia. Hortic. Res. 2015, 2, 15013. [CrossRef] [PubMed]

139. Li, C.; Yue, J.; Wu, X.; Xu, C.; Yu, J. An ABA-responsive DRE-binding protein gene from Setaria italica, SiARDP, the target gene of SiAREB, plays a critical role under drought stress. J. Exp. Bot. 2014, 65, 5415-5427. [CrossRef] [PubMed]

140. Liu, Y.; Wen, L.; Shi, Y.; Su, D.; Lu, W.; Cheng, Y.; Li, Z. Stress-responsive tomato gene SlGRAS4 function in drought stress and abscisic acid signaling. Plant Sci. 2021, 304, 110804. [CrossRef]

141. Gonzalez-Guzman, M.; Pizzio, G.A.; Antoni, R.; Vera-Sirera, F.; Merilo, E.; Bassel, G.W.; Fernández, M.A.; Holdsworth, M.J.; Perez-Amador, M.A.; Kollist, H. Arabidopsis PYR/PYL/RCAR receptors play a major role in quantitative regulation of stomatal aperture and transcriptional response to abscisic acid. Plant Cell 2012, 24, 2483-2496. [CrossRef]

142. Sivamani, E.; Bahieldin, A.; Wraith, J.M.; Al-Niemi, T.; Dyer, W.E.; Ho, T.-H.D.; Qu, R. Improved biomass productivity and water use efficiency under water deficit conditions in transgenic wheat constitutively expressing the barley HVA1 gene. Plant Sci. 2000, 155, 1-9. [CrossRef]

143. Yuasa, T.; Kubo, Y.; Fujimaki, W.; Ishii, T. Water Stress Activates The Expression of Abscisic Acid Transporter, VuABCG25, in Cowpea [Vigna unguiculata (L.) Walp.]. Cryobiol. Cryotechnology 2021, 67, 65-70.

144. Speirs, J.; Binney, A.; Collins, M.; Edwards, E.; Loveys, B. Expression of ABA synthesis and metabolism genes under different irrigation strategies and atmospheric VPDs is associated with stomatal conductance in grapevine (Vitis vinifera L. cv Cabernet Sauvignon). J. Exp. Bot. 2013, 64, 1907-1916. [CrossRef] [PubMed]

145. Soar, C.J.; Speirs, J.; Maffei, S.M.; Penrose, A.B.; McCarthy, M.G.; Loveys, B.R. Grape vine varieties Shiraz and Grenache differ in their stomatal response to VPD: Apparent links with ABA physiology and gene expression in leaf tissue. Aust. J. Grape Wine Res. 2006, 12, 2-12. [CrossRef]

146. Rossdeutsch, L.; Edwards, E.; Cookson, S.J.; Barrieu, F.; Gambetta, G.A.; Delrot, S.; Ollat, N. ABA-mediated responses to water deficit separate grapevine genotypes by their genetic background. BMC Plant Biol. 2016, 16, 1-15. [CrossRef] 
147. Xiong, C.; Zhao, S.; Yu, X.; Sun, Y.; Li, H.; Ruan, C.; Li, J. Yellowhorn drought-induced transcription factor XsWRKY20 acts as a positive regulator in drought stress through ROS homeostasis and ABA signaling pathway. Plant Physiol. Biochem. 2020, 155, 187-195. [CrossRef]

148. Brugière, N.; Zhang, W.; Xu, Q.; Scolaro, E.J.; Lu, C.; Kahsay, R.Y.; Kise, R.; Trecker, L.; Williams, R.W.; Hakimi, S. Overexpression of RING domain E3 ligase ZmXerico1 confers drought tolerance through regulation of ABA homeostasis. Plant Physiol. 2017, 175, 1350-1369. [CrossRef]

149. Qian, D.; Zhang, Z.; He, J.; Zhang, P.; Ou, X.; Li, T.; Niu, L.; Nan, Q.; Niu, Y.; He, W. Arabidopsis ADF5 promotes stomatal closure by regulating actin cytoskeleton remodeling in response to ABA and drought stress. J. Exp. Bot. 2019, 70, 435-446. [CrossRef]

150. Banerjee, A.; Roychoudhury, A. Abscisic-acid-dependent basic leucine zipper (bZIP) transcription factors in plant abiotic stress. Protoplasma 2017, 254, 3-16. [CrossRef] [PubMed]

151. Kerr, T.C.C.; Abdel-Mageed, H.; Aleman, L.; Lee, J.; Payton, P.; Cryer, D.; Allen, R.D. Ectopic expression of two AREB/ABF orthologs increases drought tolerance in cotton (Gossypium hirsutum). Plant Cell Environ. 2018, 41, 898-907. [CrossRef]

152. Wang, Y.-H.; Que, F.; Li, T.; Zhang, R.-R.; Khadr, A.; Xu, Z.-S.; Tian, Y.-S.; Xiong, A.-S. DcABF3, an ABF transcription factor from carrot, alters stomatal density and reduces ABA sensitivity in transgenic Arabidopsis. Plant Sci. 2021, 302, 110699. [CrossRef]

153. Zou, M.; Guan, Y.; Ren, H.; Zhang, F.; Chen, F. A bZIP transcription factor, OsABI5, is involved in rice fertility and stress tolerance. Plant Mol. Biol. 2008, 66, 675-683. [CrossRef] [PubMed]

154. Casaretto, J.; Ho, T.-h.D. The transcription factors HvABI5 and HvVP1 are required for the abscisic acid induction of gene expression in barley aleurone cells. Plant Cell 2003, 15, 271-284. [CrossRef] [PubMed]

155. Casaretto, J.A.; Ho, T.-h.D. Transcriptional regulation by abscisic acid in barley (Hordeum vulgare L.) seeds involves autoregulation of the transcription factor HvABI5. Plant Mol. Biol. 2005, 57, 21-34. [CrossRef] [PubMed]

156. Cho, S.K.; Ryu, M.Y.; Song, C.; Kwak, J.M.; Kim, W.T. Arabidopsis PUB22 and PUB23 are homologous U-Box E3 ubiquitin ligases that play combinatory roles in response to drought stress. Plant Cell 2008, 20, 1899-1914. [CrossRef]

157. Liu, Y.-C.; Wu, Y.-R.; Huang, X.-H.; Sun, J.; Xie, Q. AtPUB19, a U-box E3 ubiquitin ligase, negatively regulates abscisic acid and drought responses in Arabidopsis thaliana. Mol. Plant 2011, 4, 938-946. [CrossRef]

158. Ryu, M.Y.; Cho, S.K.; Kim, W.T. The Arabidopsis C3H2C3-type RING E3 ubiquitin ligase AtAIRP1 is a positive regulator of an abscisic acid-dependent response to drought stress. Plant Physiol. 2010, 154, 1983-1997. [CrossRef]

159. Lee, H.K.; Cho, S.K.; Son, O.; Xu, Z.; Hwang, I.; Kim, W.T. Drought stress-induced Rma1H1, a RING membrane-anchor E3 ubiquitin ligase homolog, regulates aquaporin levels via ubiquitination in transgenic Arabidopsis plants. Plant Cell 2009, 21, 622-641. [CrossRef]

160. Lee, S.C.; Lan, W.; Buchanan, B.B.; Luan, S. A protein kinase-phosphatase pair interacts with an ion channel to regulate ABA signaling in plant guard cells. Proc. Natl. Acad. Sci. USA 2009, 106, 21419-21424. [CrossRef]

161. Zhang, H.; Cui, F.; Wu, Y.; Lou, L.; Liu, L.; Tian, M.; Ning, Y.; Shu, K.; Tang, S.; Xie, Q. The RING finger ubiquitin E3 ligase SDIR1 targets SDIR1-INTERACTING PROTEIN1 for degradation to modulate the salt stress response and ABA signaling in Arabidopsis. Plant Cell 2015, 27, 214-227. [CrossRef] [PubMed]

162. Ko, J.H.; Yang, S.H.; Han, K.H. Upregulation of an Arabidopsis RING-H2 gene, XERICO, confers drought tolerance through increased abscisic acid biosynthesis. Plant J. 2006, 47, 343-355. [CrossRef]

163. Zhang, Y.e.; Xu, W.; Li, Z.; Deng, X.W.; Wu, W.; Xue, Y. F-box protein DOR functions as a novel inhibitory factor for abscisic acid-induced stomatal closure under drought stress in Arabidopsis. Plant Physiol. 2008, 148, 2121-2133. [CrossRef] [PubMed]

164. Meng, X.-B.; Zhao, W.-S.; Lin, R.-M.; Wang, M.; Peng, Y.-L. Molecular cloning and characterization of a rice blast-inducible RING-H2 type Zinc finger gene: Full Length Research Paper. DNA Seq. 2006, 17, 41-48. [CrossRef] [PubMed]

165. Huai, J.; Zheng, J.; Wang, G. Overexpression of a new Cys 2/His 2 zinc finger protein ZmZF1 from maize confers salt and drought tolerance in transgenic Arabidopsis. Plant Cell Tissue Organ Cult. 2009, 99, 117-124. [CrossRef]

166. Sirko, A.; Wawrzyńska, A.; Brzywczy, J.; Sieńko, M. Control of ABA Signaling and Crosstalk with Other Hormones by the Selective Degradation of Pathway Components. Int. J. Mol. Sci. 2021, 22, 4638. [CrossRef]

167. De Ollas, C.; Dodd, I.C. Physiological impacts of ABA-JA interactions under water-limitation. Plant Mol. Biol. 2016, 91, 641-650. [CrossRef]

168. Seo, P.J.; Xiang, F.; Qiao, M.; Park, J.Y.; Lee, Y.N.; Kim, S.G.; Lee, Y.H.; Park, W.J.; Park, C.M. The MYB96 transcription factor mediates abscisic acid signaling during drought stress response in Arabidopsis. Plant Physiol. 2009, 151, 275-289. [CrossRef]

169. Lu, C.; Chen, M.X.; Liu, R.; Zhang, L.; Hou, X.; Liu, S.; Ding, X.; Jiang, Y.; Xu, J.; Zhang, J.; et al. Abscisic Acid Regulates Auxin Distribution to Mediate Maize Lateral Root Development Under Salt Stress. Front. Plant Sci. 2019, 10, 716. [CrossRef] [PubMed]

170. Xu, W.; Jia, L.; Shi, W.; Liang, J.; Zhou, F.; Li, Q.; Zhang, J. Abscisic acid accumulation modulates auxin transport in the root tip to enhance proton secretion for maintaining root growth under moderate water stress. New Phytol. 2013, 197, 139-150. [CrossRef]

171. Thole, J.M.; Beisner, E.R.; Liu, J.; Venkova, S.V.; Strader, L.C. Abscisic acid regulates root elongation through the activities of auxin and ethylene in Arabidopsis thaliana. G3 2014, 4, 1259-1274. [CrossRef]

172. Bandurska, H.; Stroiński, A.; Kubiś, J. The effect of jasmonic acid on the accumulation of ABA, proline and spermidine and its influence on membrane injury under water deficit in two barley genotypes. Acta Physiol. Plant. 2003, 25, 279-285. [CrossRef]

173. De Ollas, C.; Hernando, B.; Arbona, V.; Gómez-Cadenas, A. Jasmonic acid transient accumulation is needed for abscisic acid increase in citrus roots under drought stress conditions. Physiol. Plant. 2013, 147, 296-306. [CrossRef] [PubMed] 
174. Puertolas, J.; Alcobendas, R.; Alarcón, J.J.; Dodd, I.C. Long-distance abscisic acid signalling under different vertical soil moisture gradients depends on bulk root water potential and average soil water content in the root zone. Plant Cell Environ. 2013, 36, 1465-1475. [CrossRef] [PubMed]

175. Liao, X.; Guo, X.; Wang, Q.; Wang, Y.; Zhao, D.; Yao, L.; Wang, S.; Liu, G.; Li, T. Overexpression of Ms DREB 6.2 results in cytokinin-deficient developmental phenotypes and enhances drought tolerance in transgenic apple plants. Plant J. 2017, 89, 510-526. [CrossRef]

176. Guo, Y.; Gan, S. AtMYB2 regulates whole plant senescence by inhibiting cytokinin-mediated branching at late stages of development in Arabidopsis. Plant Physiol. 2011, 156, 1612-1619. [CrossRef]

177. Huang, X.; Hou, L.; Meng, J.; You, H.; Li, Z.; Gong, Z.; Yang, S.; Shi, Y. The antagonistic action of abscisic acid and cytokinin signaling mediates drought stress response in Arabidopsis. Mol. Plant 2018, 11, 970-982. [CrossRef]

178. Gazzarrini, S.; McCourt, P. Cross-talk in plant hormone signalling: What Arabidopsis mutants are telling us. Ann. Bot. 2003, 91, 605-612. [CrossRef]

179. Leshem, Y.; Seri, L.; Levine, A. Induction of phosphatidylinositol 3-kinase-mediated endocytosis by salt stress leads to intracellular production of reactive oxygen species and salt tolerance. Plant J. 2007, 51, 185-197. [CrossRef]

180. Lorenzo, O.; Piqueras, R.; Sánchez-Serrano, J.J.; Solano, R. Ethylene response factor1 integrates signals from ethylene and jasmonate pathways in plant defense. Plant Cell 2003, 15, 165-178. [CrossRef]

181. Sharma, S.; Villamor, J.G.; Verslues, P.E. Essential role of tissue-specific proline synthesis and catabolism in growth and redox balance at low water potential. Plant Physiol. 2011, 157, 292-304. [CrossRef] [PubMed]

182. Müller, M.; Munné-Bosch, S. Ethylene response factors: A key regulatory hub in hormone and stress signaling. Plant Physiol. 2015, 169, 32-41. [CrossRef]

183. Hwang, K.; Susila, H.; Nasim, Z.; Jung, J.-Y.; Ahn, J.H. Arabidopsis ABF3 and ABF4 transcription factors act with the NF-YC complex to regulate SOC1 expression and mediate drought-accelerated flowering. Mol. Plant 2019, 12, 489-505. [CrossRef] [PubMed]

184. Yoshida, T.; Mogami, J.; Yamaguchi-Shinozaki, K. ABA-dependent and ABA-independent signaling in response to osmotic stress in plants. Curr. Opin. Plant Biol. 2014, 21, 133-139. [CrossRef] [PubMed]

185. Da Silva, E.C.; Nogueira, R.; da Silva, M.A.; de Albuquerque, M.B. Drought stress and plant nutrition. Plant Stress 2011, 5, 32-41

186. Ahanger, M.A.; Morad-Talab, N.; Abd-Allah, E.F.; Ahmad, P.; Hajiboland, R. Plant growth under drought stress: Significance of mineral nutrients. Water Stress Crop Plants A Sustain. Approach 2016, 2, 649-668.

187. Wu, Z.Z.; Ying, Y.Q.; Zhang, Y.B.; Bi, Y.F.; Wang, A.K.; Du, X.H. Alleviation of drought stress in Phyllostachys edulis by N and P application. Sci. Rep. 2018, 8, 1-9. [CrossRef]

188. Hosseini, S.A.; Réthoré, E.; Pluchon, S.; Ali, N.; Billiot, B.; Yvin, J.-C. Calcium application enhances drought stress tolerance in sugar beet and promotes plant biomass and beetroot sucrose concentration. Int. J. Mol. Sci. 2019, 20, 3777. [CrossRef]

189. Zahoor, R.; Dong, H.; Abid, M.; Zhao, W.; Wang, Y.; Zhou, Z. Potassium fertilizer improves drought stress alleviation potential in cotton by enhancing photosynthesis and carbohydrate metabolism. Environ. Exp. Bot. 2017, 137, 73-83. [CrossRef]

190. Agami, R.A.; Alamri, S.A.; Abd El-Mageed, T.; Abousekken, M.; Hashem, M. Role of exogenous nitrogen supply in alleviating the deficit irrigation stress in wheat plants. Agric. Water Manag. 2018, 210, 261-270. [CrossRef]

191. El-Mageed, A.; Taia, A.; Shaaban, A.; El-Mageed, A.; Shimaa, A.; Semida, W.M.; Rady, M.O. Silicon defensive role in maize (Zea mays L.) against drought stress and metals-contaminated irrigation water. Silicon 2021, 13, 2165-2176. [CrossRef]

192. Nawaz, F.; Shehzad, M.A.; Majeed, S.; Ahmad, K.S.; Aqib, M.; Usmani, M.M.; Shabbir, R.N. Role of Mineral Nutrition in Improving Drought and Salinity Tolerance in Field Crops; Springer: Singapore, 2020; pp. 129-147.

193. Riboni, M.; Robustelli Test, A.; Galbiati, M.; Tonelli, C.; Conti, L. ABA-dependent control of GIGANTEA signalling enables drought escape via up-regulation of flowering locus $\mathrm{T}$ in Arabidopsis thaliana. J. Exp. Bot. 2016, 67, 6309-6322. [CrossRef] [PubMed]

194. Riboni, M.; Galbiati, M.; Tonelli, C.; Conti, L. Gigantea enables drought escape response via abscisic acid-dependent activation of the florigens and suppressor of overexpression of constans1. Plant Physiol. 2013, 162, 1706-1719. [CrossRef] [PubMed]

195. Du, H.; Huang, F.; Wu, N.; Li, X.; Hu, H.; Xiong, L. Integrative regulation of drought escape through ABA-dependent andindependent pathways in rice. Mol. Plant 2018, 11, 584-597. [CrossRef] [PubMed]

196. Yu, W.; Zhao, R.; Wang, L.; Zhang, S.; Li, R.; Sheng, J.; Shen, L. ABA signaling rather than ABA metabolism is involved in trehalose-induced drought tolerance in tomato plants. Planta 2019, 250, 643-655. [CrossRef]

197. Martignago, D.; Siemiatkowska, B.; Lombardi, A.; Conti, L. Abscisic Acid and Flowering Regulation: Many Targets, Different Places. Int. J. Mol. Sci. 2020, 21, 9700. [CrossRef] [PubMed]

198. Shavrukov, Y.; Kurishbayev, A.; Jatayev, S.; Shvidchenko, V.; Zotova, L.; Koekemoer, F.; de Groot, S.; Soole, K.; Langridge, P. Early flowering as a drought escape mechanism in plants: How can it aid wheat production? Front. Plant Sci. 2017, 8, 1950. [CrossRef]

199. Lim, C.W.; Baek, W.; Jung, J.; Kim, J.-H.; Lee, S.C. Function of ABA in stomatal defense against biotic and drought stresses. Int. J. Mol. Sci. 2015, 16, 15251-15270. [CrossRef] [PubMed]

200. Bhaskara, G.B.; Yang, T.-H.; Verslues, P.E. Dynamic proline metabolism: Importance and regulation in water limited environments. Front. Plant Sci. 2015, 6, 484. [CrossRef]

201. Ghate, T.; Barvkar, V.; Deshpande, S.; Bhargava, S. Role of ABA signaling in regulation of stem sugar metabolism and transport under post-flowering drought stress in sweet sorghum. Plant Mol. Biol. Rep. 2019, 37, 303-313. [CrossRef] 